\title{
Water availability, demand and reliability of in situ water harvesting in smallholder rain-fed agriculture in the Thukela River Basin, South Africa
}

\author{
J. C. M. Andersson ${ }^{1,2}$, A. J. B. Zehnder ${ }^{3}$, G. P. W. Jewitt ${ }^{4}$, and H. Yang ${ }^{1}$ \\ ${ }^{1}$ Eawag, Swiss Federal Institute of Aquatic Science and Technology, 8600 Dübendorf, Switzerland \\ ${ }^{2}$ Institute of Biogeochemistry and Pollutant Dynamics, ETH Zurich, 8092 Zurich, Switzerland \\ ${ }^{3}$ Alberta Water Research Institute (AWRI), Edmonton, Alberta, Canada \\ ${ }^{4}$ School of Bioresources Engineering and Environmental Hydrology, University of KwaZulu-Natal, Private Bag X01, \\ Scottsville 3209, South Africa
}

Received: 5 June 2009 - Published in Hydrol. Earth Syst. Sci. Discuss.: 13 July 2009

Revised: 12 November 2009 - Accepted: 19 November 2009 - Published: 9 December 2009

\begin{abstract}
Water productivity in smallholder rain-fed agriculture is of key interest for improved food and livelihood security. A frequently advocated approach to enhance water productivity is to adopt water harvesting and conservation technologies (WH). This study estimates water availability for potential in situ WH, and supplemental water demand (SWD) in smallholder agriculture in South Africa's Thukela River Basin $\left(29000 \mathrm{~km}^{2}\right.$, mean annual precipitation $550-2000 \mathrm{~mm} \mathrm{yr}^{-1}$ ). The study includes process dynamics governing runoff generation and crop water demands, quantification of prediction uncertainty, and an analysis of the reliability of in situ WH.

The agro-hydrological model SWAT (Soil and Water Assessment Tool) was calibrated and evaluated with the Sequential Uncertainty Fitting algorithm against observed discharge (at ten stations) and maize yield (the dominant crop type) for the period 1997-2006. The water availability was based on the generated surface runoff in smallholder areas. The SWD was derived from a scenario where crop water deficits were met from an unlimited external water source. The reliability was calculated as the percentage of years in which water availability $\geq$ SWD. This reflects the risks of failure induced by the temporal variability in the water availability and the SWD.

The calibration reduced the predictive uncertainty and resulted in a satisfactory model performance. For smallholder maize yield, the Root Mean Squared Error was $0.02 \mathrm{tha}^{-1}$
\end{abstract}

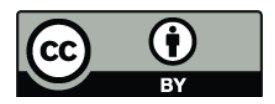

Correspondence to: J. C. M. Andersson (jafet.andersson@eawag.ch) during both the calibration and the evaluation periods. The width of the uncertainty band was reduced by $23 \%$ due to the calibration. For discharge during the calibration (evaluation) period, the ten-station range in the weighted coefficient of determination $(\Phi)$ was $0.16-0.85(0.18-0.73)$, and in the coefficient of determination $\left(R^{2}\right) 0.42-0.83(0.28-0.72)$. The calibration reduced the width of the uncertainty band by $25 \%$ on average.

The results show that the smallholder crop water productivity is currently low in the basin (spatiotemporal median: $0.08-0.22 \mathrm{~kg} \mathrm{~m}^{-3}, 95 \%$ prediction uncertainty band (95PPU)). Water is available for in situ WH (spatiotemporal median: $0-17 \mathrm{~mm}_{\text {year }}{ }^{-1}, 95 \mathrm{PPU}$ ) which may aid in enhancing the crop water productivity by meeting some of the SWD (spatiotemporal median: 0-113 $\mathrm{mm}$ year $^{-1}$, 95PPU). However, the reliability of in situ WH is highly location specific and overall rather low. Of the $1850 \mathrm{~km}^{2}$ of smallholder lands, $20-28 \%$ display a reliability $\geq 25 \%, 13-16 \%$ a reliability $\geq 50 \%$, and $4-5 \%$ a reliability $\geq 75 \%$ (95PPU). This suggests that the risk of failure of in situ WH is relatively high in many areas of the basin.

\section{Introduction}

Approximately 850 million people currently live in food insecurity, often linked with water scarcity, poverty and stressed ecosystems (FAO, 2009). An expected additional 12 billion people will need to be fed by 2025 (UN, 2009). This translates to a veritable water resources challenge in waterlimited areas because of the large amounts of water required

Published by Copernicus Publications on behalf of the European Geosciences Union. 
for food production. The strategies to manage water efficiently, and achieve food and livelihood security are numerous and of varied success (Yang and Zehnder, 2007).

A family of strategies focuses on increasing food production on existing agricultural land, avoiding horizontal expansion of low-productivity agriculture, and not further stressing water-limited systems by improving the crop water productivity. Of particular interest in this regard is smallholder rainfed farming in sub-Saharan Africa (SSA) (Rockström et al., 2004). SSA is significant due to high levels of undernourishment, rapid population growth, and a considerable degree of water stress (Schuol et al., 2008; FAO, 2009). Rain-fed systems are essential for improved food security because of the high degree of reliance of the food insecure population on these systems (Liu et al., 2008). Increasing the crop water productivity in smallholder farming is key since the productivity is often low but has the largest potential to be enhanced (Molden, 2007).

A frequently advocated approach to enhance water productivity in smallholder rain-fed agriculture is to adopt water harvesting and conservation technologies (WH) such as tied ridges and contour bunds, micro-basins, mulching, runoff harvesting, and other conservation farming technologies (Rockström et al., 2004; Gurtner et al., 2006). The core aim of WH is to enhance the resilience of the agroecosystems to some of the biophysical challenges in the tropical savannah biome such as the high spatiotemporal variability in precipitation, and the low soil fertility. The high variability in precipitation causes frequent dry spells and sometimes high water stress during critical crop-growth stages. This often results in low yields and high yield variability (Rockström, 2003). The key function of WH is to alter the partitioning of precipitation into less surface runoff and more soil moisture; and partition more of the soil moisture into crop transpiration and less to soil evaporation. Thus, WH seeks to raise crop water productivity, yields and yield stability (Falkenmark and Rockström, 2004; Rockström and Barron, 2007). In situ WH refer to all technologies which alter the rainfall partitioning of the agricultural fields themselves, while external WH systems concentrate runoff from uncultivated areas onto the agricultural fields (sometimes via storage and supplemental irrigation systems).

The capacity of the WH strategy to fulfil its aim is influenced by a number of spatially varying factors (e.g. rainfall and soil type (FAO, 2003; Ali et al., 2007)). For effective policy-making, it is of key interest to identify the set of potential locations where such factors converge and implementation of WH may be appropriate; i.e. the suitability of a given WH technology. Previous contributions to WH suitability have focussed on various types and purposes of $\mathrm{WH}$, and various aspects influencing the suitability across a range of spatial scales (Table 1).

The surface runoff generation potential constitutes a key component of most suitability studies because it is the principal water source for WH (Makurira et al., 2009). Repar- titioning from runoff to infiltration has been the principal mechanism through which WH has enhanced crop yield and water productivity on the field scale. Repartitioning from evaporation to transpiration is difficult in the tropical savannah biome because of the high atmospheric evaporative demand, low canopy cover and high opportunity cost of crop residues (Rockström, 2003). The runoff generation potential is primarily estimated either as a ranked runoff level by combining soil, slope, and land use datasets; or as a quantified runoff amount using climatic datasets together with static antecedent soil moisture conditions (AM) and static runoff thresholds (Table 1). The advantage of these estimation methods is their ease of application with readily available datasets. However, they run the risk of over-generalisation by not accounting for the critical temporal variability in e.g. AM and consequential runoff generation potential from a given rainfall event.

Agricultural water use is the most frequent intended purpose of WH in suitability assessments (Table 1). Potential crop water demands are, however, seldom estimated. If included, they are generally estimated as static in time and generic in space. That is despite equally significant spatiotemporal variability in e.g. dry-spell occurrence. This affects the amount of demanded water because of the variability in water demand over the crop growth cycle.

The high variability in climatic conditions in the savannah biome implies that water is not available or demanded everywhere or all the time. Therefore, implementation of $\mathrm{WH}$ at any given location involves a degree of risk acceptance that the system may fail to raise crop yields or water productivity. Inclusion of explicit risk accounts may render WH suitability characterisations more transparent and more appropriate for effective and flexible decision-making. Some attempts have been made to assess this risk on the local scale (e.g. Ngigi et al., 2005; Walker et al., 2005; de Winnaar et al., 2007). However, most large-scale integrated suitability assessments implicitly assume a fixed risk level (e.g. considering average annual conditions, Table 1). The reliability of a given WH system, expressed as the percentage of time that the water availability equals or exceeds the crop water demand, is here taken as an indicator of the degree of this risk. A high reliability represents a low risk of failure.

The uncertainty of component datasets and process simulations constituting the foundation of suitability estimates is often rather large (Jewitt, 2006). However, suitability estimates generally lack an uncertainty account without which an unreasonably high level of confidence may be attributed to their predictions (Table 1).

Against this background, the objective of this study was to estimate the water availability for potential in situ $\mathrm{WH}$, and water demands in smallholder agricultural systems by incorporating: (1) spatiotemporal process dynamics governing (i) runoff generation and (ii) crop water demands, (2) quantification of prediction uncertainty, and (3) an analysis of the reliability of in situ WH. The focus was on the Thukela River 
Table 1. Overview of approaches to identify potentially suitable locations of WH. AM is antecedent soil moisture conditions.

\begin{tabular}{|c|c|c|c|c|c|c|c|}
\hline Study & Type of WH & Purpose of WH & Spatial scale & $\begin{array}{l}\text { Method of water availability } \\
\text { estimation }\end{array}$ & $\begin{array}{l}\text { Method of water } \\
\text { demand estimation }\end{array}$ & $\begin{array}{l}\text { System reliability } \\
\text { consideration }\end{array}$ & $\begin{array}{l}\text { Uncertainty } \\
\text { consideration }\end{array}$ \\
\hline This study & in situ WH & $\begin{array}{l}\text { Alleviating field } \\
\text { crop water } \\
\text { eficits }\end{array}$ & $\begin{array}{l}\text { Thukela River } \\
\text { Basin, South Africa } \\
\left(2.9 \times 10^{4} \mathrm{~km}^{2}\right)\end{array}$ & $\begin{array}{l}\text { Daily simulation with } \\
\text { dynamic adjustment of AM } \\
\text { and runoff thresholds. }\end{array}$ & $\begin{array}{l}\text { Daily simulation of } \\
\text { and crop water deficits with } \\
\text { dynamic phenological } \\
\text { development }\end{array}$ & $\begin{array}{l}\text { Yes, for runoff } \\
\text { and crop water } \\
\text { deficits }\end{array}$ & Yes \\
\hline $\begin{array}{l}\text { de Winnaar } \\
\text { et al. (2007) }\end{array}$ & $\begin{array}{l}\text { Runoff-harvesting } \\
\text { and small } \\
\text { reservoir storage }\end{array}$ & $\begin{array}{l}\text { Supplemental } \\
\text { irrigation for } \\
\text { homestead }\end{array}$ & $\begin{array}{l}\text { Potshini } \\
\text { community, } \\
\text { Thukela, South }\end{array}$ & $\begin{array}{l}\text { Static runoff thresholds and } \\
\text { AM on ranked soil, slope } \\
\text { and land use classes. }\end{array}$ & $\begin{array}{l}\text { Indirect: distance to } \\
\text { crop fields and } \\
\text { homesteads }\end{array}$ & Yes, for rainfall & No \\
\hline $\begin{array}{l}\text { Mbilinyi } \\
\text { et al. (2007) }\end{array}$ & $\begin{array}{l}\text { in situ } \mathrm{WH} \text { and } \\
\text { small reservoir } \\
\text { storage }\end{array}$ & $\begin{array}{l}\text { gardens } \\
\text { Alleviating field } \\
\text { crop water } \\
\text { deficits and } \\
\text { water stress }\end{array}$ & $\begin{array}{l}\text { Africa }\left(1.2 \mathrm{~km}^{2}\right) \\
\text { Makanya } \\
\text { catchment, } \\
\text { Tanzania }\left(200 \mathrm{~km}^{2}\right)\end{array}$ & $\begin{array}{l}\text { Indirect: Weighted overlay of } \\
\text { ranked rainfall, land use soil, } \\
\text { slope, and drainage. }\end{array}$ & Not estimated & No & No \\
\hline $\begin{array}{l}\text { Ramakrishnan } \\
\text { et al. (2008) }\end{array}$ & $\begin{array}{l}\text { Check dams, } \\
\text { percolation ponds }\end{array}$ & Multiple & $\begin{array}{l}\text { Kali catchment, } \\
\text { India }\left(200 \mathrm{~km}^{2}\right)\end{array}$ & $\begin{array}{l}\text { Mean monthly water balance } \\
\text { simulation. }\end{array}$ & Not estimated. & No & No \\
\hline $\begin{array}{l}\text { Kahinda } \\
\text { et al. (2008) }\end{array}$ & $\begin{array}{l}\text { in situ WH and } \\
\text { ex situ WH }\end{array}$ & $\begin{array}{l}\text { Alleviating field } \\
\text { crop water } \\
\text { deficits }\end{array}$ & $\begin{array}{l}\text { South Africa } \\
\left(1.2 \times 10^{6} \mathrm{~km}^{2}\right)\end{array}$ & $\begin{array}{l}\text { Indirect: weighted overlay of } \\
\text { ranked rainfall, land use and } \\
\text { soil. }\end{array}$ & $\begin{array}{l}\text { Indirect: domestic } \\
\text { availability of piped } \\
\text { water (static) }\end{array}$ & No & No \\
\hline $\begin{array}{l}\text { Hensley } \\
\text { et al. (2007) }\end{array}$ & in situ WH & $\begin{array}{l}\text { Alleviating field } \\
\text { crop water } \\
\text { deficits }\end{array}$ & $\begin{array}{l}\text { South Africa } \\
\left(1.2 \times 10^{6} \mathrm{~km}^{2}\right)\end{array}$ & $\begin{array}{l}\text { Indirect: soil depth and water } \\
\text { holding capacity } \\
\text { classification. }\end{array}$ & Not estimated. & No & No \\
\hline Mati et al. (2006) & $\begin{array}{l}\text { Roof tanks, } \\
\text { runoff-harvesting, } \\
\text { sand dams, } \\
\text { in situ WH }\end{array}$ & Multiple & $\begin{array}{l}\text { Africa } \\
\left(3 \times 10^{7} \mathrm{~km}^{2}\right) \\
\text { datasets with static runoff } \\
\text { threshold. }\end{array}$ & $\begin{array}{l}\text { Overlay of rainfall, slope, } \\
\text { land use, drainage network }\end{array}$ & Population density. & No & No \\
\hline $\begin{array}{l}\text { Senay and Verdin } \\
\text { (2004) }\end{array}$ & $\begin{array}{l}\text { Runoff-harvesting } \\
\text { and small } \\
\text { reservoir storage }\end{array}$ & $\begin{array}{l}\text { Field crop } \\
\text { irrigation }\end{array}$ & $\begin{array}{l}\text { Africa } \\
\left(3 \times 10^{7} \mathrm{~km}^{2}\right) \\
\text { thresholds. }\end{array}$ & $\begin{array}{l}\text { Daily simulation with 5-day } \\
\text { updating of AM and runoff } \\
\text { water demand }\end{array}$ & $\begin{array}{l}\text { Static and generic } \\
\text { African average crop }\end{array}$ & No & No \\
\hline
\end{tabular}

Basin in South Africa because the WH strategy has been suggested to hold some degree of potential in the basin, given its erratic and predominantly semi-arid climate and extensive smallholder farming communities with a history of low crop yields. In addition, field-scale measurements and local suitability assessments of WH have been conducted in the basin (Kongo and Jewitt, 2006; de Winnaar et al., 2007; Kosgei et al., 2007). This provides the opportunity to compare basinscale simulation outputs with local data in specific areas.

\section{Methodology}

\subsection{Study area}

The Thukela River Basin in South Africa (Fig. 1) is a diverse basin stretching over approximately $29000 \mathrm{~km}^{2}$ from an altitude of over $3000 \mathrm{~m}$ in the Ukhahlamba-Drakensberg World Heritage Site to sea level at the Indian Ocean. Its climate is characterised by dry cool winters, warm summers with intensive precipitation, and a high spatiotemporal variability. The mean annual precipitation ranges from $550 \mathrm{~mm} \mathrm{yr}^{-1}$ in the central regions to $2000 \mathrm{~mm} \mathrm{yr}^{-1}$ in the mountainous west of the basin. In the upper catchment, rainfall is highly seasonal with over $90 \%$ falling between October and March, and commonly zero precipitation in the dry winter months. The mean annual potential evapotranspiration ranges between 1600 and $2000 \mathrm{~mm} \mathrm{yr}^{-1}$. The mean daily maximum temperature in
January ranges from 20 to $32^{\circ} \mathrm{C}$, and the mean daily minimum temperature in July ranges from 0 to $10^{\circ} \mathrm{C}$ (Taylor et al., 2001). The basin is relatively water rich, with multiple reservoirs and transfer schemes supplying water as far away as Johannesburg. In contrast, many rural communities in the basin lack piped water supply and rely on local groundwater or river discharge for their water needs.

The dominant land use in the basin is unimproved grassland, whereas the major anthropogenic land uses are agriculture, livestock grazing and forestry (Table 2, CSIR et al., 2002). Chromic Vertisols and Orthic Luvisols dominate the basin (Table 3). There is a duality of agricultural systems with both large-scale ( $>700 \mathrm{ha}$ ) commercial farmers and small-scale (ca. $1.5 \mathrm{ha}$ ) smallholder farmers (Taylor et al., 2001; Kosgei et al., 2007). The commercial systems are characterised by a high level of mechanisation, utilisation of fertilisers, commercial cultivars, and other inputs in both irrigated and rain-fed production systems. The smallholder systems are predominantly rain-fed, use local cultivars, and low amounts of fertilisers and other inputs. The main cultivated crop types in the commercial systems are maize, soybean, sorghum, and winter wheat. Maize dominates the smallholder systems (Statistics South Africa, 2006; Kosgei et al., 2007). The commercial irrigated systems principally utilise surface water for irrigation through sophisticated irrigation systems consisting of linked storage and transfer schemes, off-channel storage, withdrawals from rivers, blocking small streams or catching hillside runoff 


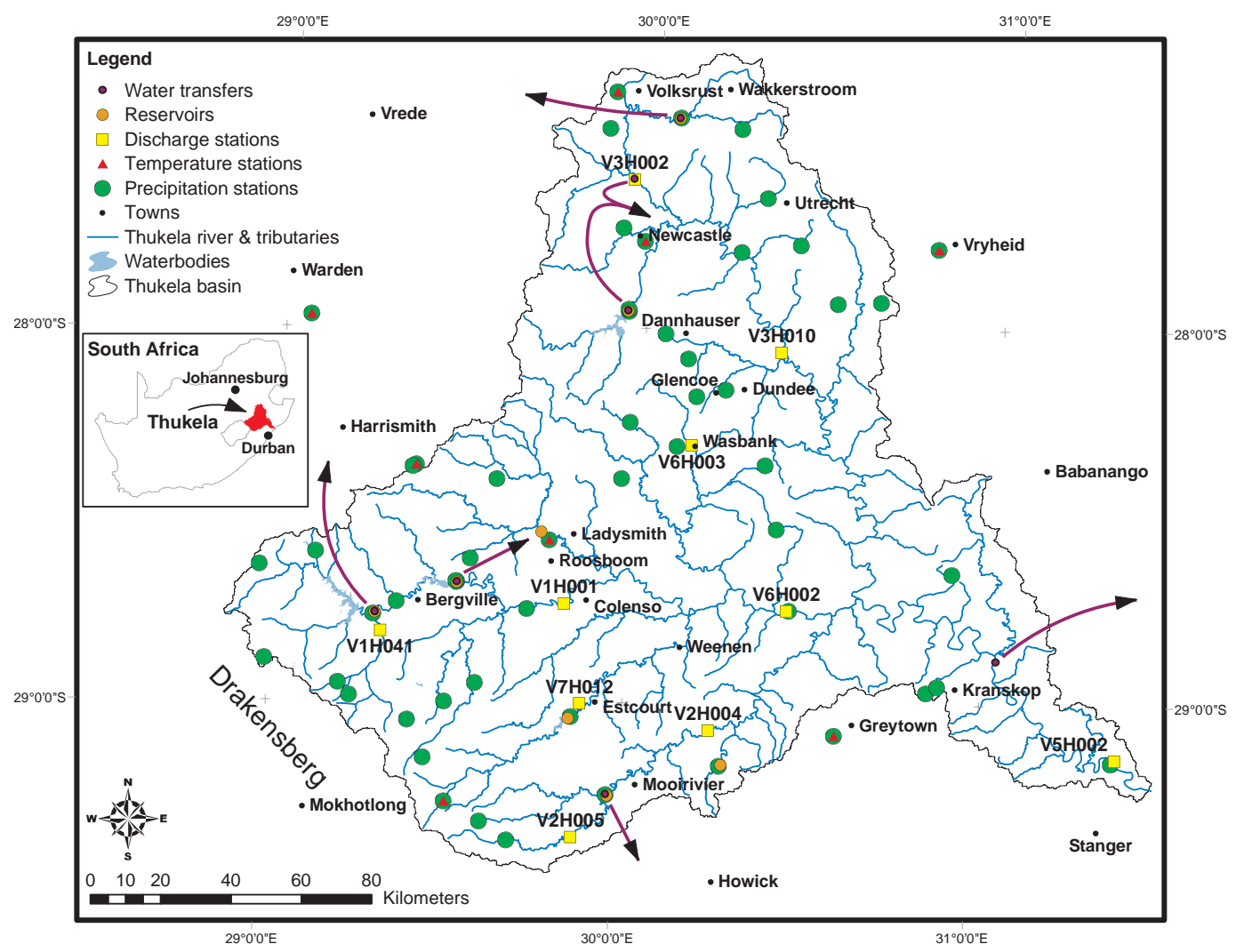

Fig. 1. Overview of the Thukela River Basin and the major precipitation, temperature and discharge stations as well as reservoirs and water transfers (purple arrows) included in the model. Projection: Lambert Azimutal Equal Area. Datum: GCS_WGS1984.

with small dams. Although smallholder systems are mainly rain-fed, some small-scale irrigation schemes have been instigated with varied success. There are ongoing efforts to promote WH in the basin through e.g. the LandCare project (Smith, 2006) and the Smallholder Systems Initiative (Rockström et al., 2004). Both projects targeted rural community adoption of a set of WH techniques including conservation tillage, cover cropping, mulching as well as small surface and subsurface storage schemes in the Bergville area. Aside from the adoption stemming from these projects, the present adoption of WH techniques intended for smallholder agriculture is negligible in the basin. By contrast, many of the commercial farmers have adopted conservation tillage practices already.

\subsection{Model, data and setup}

\subsubsection{The SWAT model}

The Soil and Water Assessment Tool (SWAT, Arnold et al., 1998) was used to simulate hydrological and vegetationgrowth processes in the Thukela basin. SWAT was chosen because of the close linkage between its development purpose and the objectives of this project, open access to the
Table 2. Dominant land cover classes in the basin derived from the South African National Land Cover dataset (CSIR et al., 2002).

\begin{tabular}{lc}
\hline Class & $\begin{array}{c}\text { Area } \\
\text { (\% of basin) }\end{array}$ \\
\hline Unimproved (natural) grassland & 54.4 \\
Thicket, bushland, bush clumps, high fynbos & 16.1 \\
Degraded unimproved (natural) grassland & 7.9 \\
Cultivated, smallholder, rain-fed & 6.4 \\
Cultivated, commercial, rain-fed & 6.1 \\
Degraded thicket, bushland, bush clumps, high fynbos & 3.1 \\
Cultivated, commercial, irrigated & 2.2 \\
Other & 3.8 \\
\hline
\end{tabular}

source code, and its successful application in a wide range of scales and environmental conditions, including humid, temperate and semi-arid climates (Van Liew and Garbrecht, 2003; Bouraoui et al., 2005; Neitsch et al., 2005; Gassman et al., 2007).

SWAT is a physical-conceptual, spatially distributed model operating on a daily time step. The spatial characterisation of a river basin is carried out by topographically dividing the basin into multiple sub-basins. Each sub-basin is divided into hydrological response units (HRU) based on 
Table 3. Major soil types of the basin. Moist bulk density, organic carbon content, hydraulic conductivity and available water capacity are presented for the top layer of the soil profile $(0-30 \mathrm{~cm}$ depth).

\begin{tabular}{lclccccc}
\hline FAO soil unit & $\begin{array}{c}\text { Area } \\
(\% \text { of } \\
\text { basin })\end{array}$ & Texture & $\begin{array}{c}\text { Maximum } \\
\text { rooting } \\
\text { depth }(\mathrm{cm})\end{array}$ & $\begin{array}{c}\text { Moist } \\
\text { bulk } \\
\text { density } \\
\left(\mathrm{g} \mathrm{cm}^{-3}\right)\end{array}$ & $\begin{array}{c}\text { Organic carbon } \\
\text { content } \\
(\% \text { soil weight })\end{array}$ & $\begin{array}{c}\text { Saturated } \\
\text { hydraulic } \\
\text { conductivity } \\
\left(\mathrm{mm} \mathrm{hr}^{-1}\right)\end{array}$ & $\begin{array}{c}\text { Available water } \\
\text { capacity } \\
\left(\mathrm{mm} \mathrm{H} \mathrm{H}_{2} \mathrm{O} \text { per }\right. \\
\mathrm{mm} \mathrm{soil}^{2}\end{array}$ \\
\hline Chromic Vertisol & 41.97 & Clay-loam & 81 & 1.3 & 1.2 & 7.43 & 0.12 \\
Orthic Luvisol & 31.83 & Loam & 91 & 1.4 & 0.6 & 6.87 & 0.16 \\
Rhodic Ferralsol & 14.41 & Clay & 96 & 1.2 & 1.5 & 16.07 & 0.16 \\
Lithosol & 5.53 & Clay-loam & 69 & 1.2 & 2.2 & 13.14 & 0.12 \\
Eutric Cambisol & 4.90 & Clay-loam & 91 & 1.2 & 1.0 & 12.35 & 0.16 \\
Eutric Cambisol & 0.79 & Sandy-loam & 91 & 1.4 & 0.8 & 20.18 & 0.13 \\
Chromic Vertisol & 0.39 & Clay & 100 & 1.5 & 0.8 & 2.84 & 0.14 \\
\hline
\end{tabular}

land use, soil, and slope classes. In each HRU and on each day the hydrological and vegetation-growth processes are simulated based on the Curve Number rainfall-runoff partitioning method (accounting for AM) and the heat unit phenological development method (Neitsch et al., 2005). Discharge-sustaining processes are aggregated to sub-basin level and routed to the basin outlet.

Energy availability governs vegetation phenology. At each point in the growth cycle, biomass production is derived from the interception of solar radiation by leaves, plant-specific radiation-use-efficiency and leaf area index (LAI). A set of parameters characterise leaf area development for each vegetation type, from which LAI is derived. Crop yield is calculated at harvest by multiplying the above-ground biomass with the harvest index. The harvest index is the fraction of the above-ground plant dry biomass removed as dry economic yield. The biomass remaining after harvest is converted to residue on the soil surface, modifying the soil cover and the soil water balance. Plant growth is limited by temperature, water, and nutrient availability in the soil; and is influenced by agricultural management (e.g. fertilisation, irrigation, and timing of operations). For more details the interested reader should refer to Neitsch et al. (2005).

\subsubsection{Model setup and input data}

The ArcSWAT interface (Olivera et al., 2006) as well as the $\mathrm{R}$ statistical computing environment ( $\mathrm{R}$ Development Core Team, 2008) were utilised in project setup and analysis. The HydroSHEDS hydrologically conditioned digital elevation model at 3 arc-second spatial resolution (Lehner et al., 2006) was employed to derive slope and drainage network, and to delineate the sub-basins. The sub-basins were delineated with a $\geq 2025$ ha threshold based on verification against fieldvalidated drainage-network data yielding 847 sub-basins in total. The soil data used for hydro-pedological parameter information was the FAO-UNESCO global soil map (FAO, $1995)$ with two soil layers at 1:5000,000 scale, supplemented by data from Reynolds et al. (1999) and the ROSETTA model (Kosugi, 1999). Two land cover datasets were utilised: the South African National Land Cover 2000 (NLC) dataset (CSIR et al., 2002) and the South African Crop Field Boundaries (CFB) dataset (NCSC, 2007)). The CFB (native resolution $10 \mathrm{~m}$ ) was used to simulate the crop fields, and the NLC (native resolution $30 \mathrm{~m}$ ) for all other land use classes. The NLC was resampled to CFB resolution in order not to loose crop field resolution. The combined dataset was parameterised for SWAT based on Schuol et al. (2008) supplemented by local information (e.g. the South Africa Curve Number method, Schulze et al., 2004). Each sub-basin was split into unique combinations of land use classes and soil types to individually capture the different land use systems' agro-hydrological characteristics, resulting in 3754 HRUs in total.

The climatic inputs consisted of daily data on precipitation, maximum and minimum temperatures from a set of stations in the basin; and hourly solar radiation from the Durban Airport Weather Office (Fig. 1). The simulation period was 1 January 1994 to 31 December 2006 based on the availability of land use, crop yield, discharge, and climatic data. The first three years were used for model initialisation and were not included in subsequent analyses. The climatic data originated from Lynch (2003), the South African Weather Service (www.weathersa.co.za, access: 12 March 2009), and the South African Department of Water Affairs and Forestry (DWAF, www.dwaf.gov.za, access: 12 March 2009). Only stations with $<20 \%$ missing data were included and the weather generator of SWAT was used to fill remaining gaps. Hourly precipitation data from a station near Bergville was used to improve the parameterisation of peak rainfall intensity (driving sub-daily peak runoff rate) in the weather generator (Kongo et al., 2007). Potential evapotranspiration was estimated by the Hargreaves method, while actual evapotranspiration $\left(E_{T}\right)$ was simulated based on Ritchie (1972). The daily value of leaf area index was used to partition between evaporation and transpiration. 
Available quantitative data on water management was incorporated in the model. This was daily DWAF data on major reservoir outflows and water transfers in the basin (Fig. 1). The records contained only minor amounts of missing values (on average 3\%), which were approximated using LOESS interpolation (Cleveland et al., 1992). Reservoirs were simulated as impoundments on the main river channels, each with its respective water balance. The measured reservoir outflow fed the downstream river network, and the reservoir balance was calculated by accounting for this outflow. Reported withdrawal data fed the water transfer simulations. The conveyance efficiency between withdrawal and discharge was estimated from the transfer scheme near the Thukela river mouth to ca. $53 \%$ (Fig. 1).

The two major agricultural systems were simulated on each relevant land cover class. The management of the smallholder systems was modelled as rain-fed maize without added inorganic fertilisers. Timing of planting, harvest, and mouldboard plough tillage was based on field-scale research and assumed uniformity in space and time (Kosgei et al., 2007). The parameterisation of the cultivar type was derived from climatic data and local expertise (J. Kosgei, personal communication, 2008). The commercial systems were simulated as rain-fed or irrigated according to their respective land cover class. Irrigation was based on plantwater-stressed automatic scheduling, and withdrawn from local reaches. The four major crop types were simulated on both rain-fed and irrigated lands in proportions derived from provincial-level data (Statistics South Africa, 2006). Single cropping was assumed based on reported cropping intensity (FAO, 2005). Cultivar parameterisation and timing of operations originated from Schulze (2007), ARC (2008), du Toit (1999) and Ma'ali (2007). All irrigated and most rain-fed commercial system HRUs were fertilised with inorganic fertilisers based on crop-type specific proportions and compositions given by the Fertiliser Society of South Africa (www.fssa.org.za, access: 13 March 2009). Plant-nutrient deficit automatic fertilisation scheduling was employed, and the annual maximum application amount was derived from ARC (2008). The locations of crop type and fertiliser usage were randomly distributed among the commercial system HRUs according to their respective proportions because no additional information on their spatial distribution was available. Tillage effects of commercial farmers were assumed to be captured in the calibration process. Remaining crop parameters, and parameters for non-crop land covers, originated from the SWAT default database (Neitsch et al., 2005). Parameters sensitive to model outputs were subsequently calibrated to the local conditions.

\subsection{Calibration, evaluation and uncertainty procedure}

The model was calibrated against local observations of discharge, maize yield in smallholder systems, and maize yield in commercial systems. The calibration period was 1 January 2002 to 31 December 2006. The period 1 January 1997 to 31 December 2001 was used as an independent evaluation period in which the predictive power of the model was tested. DWAF datasets from ten nested discharge stations on daily temporal resolution were used (Fig. 1). The choice of discharge stations was based on homogeneity of spatial distribution, range of scales in drainage areas, availability of data, and avoidance of clear upstream reservoir influence. The maize yields were calibrated on annual and basin-wide resolution, and the data originated from the Crop Estimate Committee of the South African Department of Agriculture (CEC, www.nda.agric.za, access: 12 March 2009).

The Sequential Uncertainty Fitting algorithm (SUFI-2) was used for calibration and uncertainty analysis (Abbaspour and Johnson, 2004; Abbaspour et al., 2007). SUFI-2 was chosen because of its ability to analyse multiple parameters and output variables simultaneously, and because of the computational efficiency of the algorithm relative to other calibration and uncertainty estimation techniques (Yang et al., 2008). In SUFI-2 all sources of uncertainty are mapped to a set of parameter ranges. They are calibrated with the dual aim of bracketing most of the observed data with an as narrow as possible uncertainty band in a Bayesian approach. Initial parameter ranges were based on physically meaningful limits. Within the ranges, 500 Latin hypercube parameter set samples were drawn for each calibration iteration. In each iteration 500 simulations were run, where each simulation corresponded to one parameter set sample.

The selection of parameters to calibrate was based on a sensitivity analysis similar to Muleta and Nicklow (2005). A broad set of initial parameters were derived from Lenhart et al. (2002); van Griensven et al. (2006); Holvoet et al. (2005); Abbaspour et al. (2007); Ruget et al. (2002); Wang et al. (2005); Liu (2009); Faramarzi et al. (2009), and Neitsch et al. (2005). A set of Latin hypercube samples were drawn from the parameter ranges and the objective functions were calculated for each of these. A step-wise regression analysis was carried out between parameter values and objective functions. Parameters significantly influencing the objective functions were chosen for calibration. Some parameters were also included because they influenced the hydrograph patterns relative to observed data (Table 4). Spatially distributed parameters affecting discharge were grouped into ten calibration regions according to the nearest downstream discharge station and calibrated in parallel in order to better capture the region-specific and scale-specific difference between them (Faramarzi et al., 2009). For the crop related parameters, one parameter group was used for all smallholder HRUs and another for all commercial maize-growing HRUs (Table 4). 
Table 4. Parameter sensitivity of calibrated parameters in relation to the objective function values for discharge (d), smallholder maize yield (s), and commercial maize yield (c), respectively. The $t$-value indicates parameter sensitivity: the larger the absolute $t$-value, the more sensitive the parameter. The $p$-value indicates the significance of the $t$-value: the smaller the $p$-value, the less chance of a parameter being accidentally assigned as sensitive.

\begin{tabular}{|c|c|c|c|c|}
\hline Parameter & Definition & $\begin{array}{c}\text { Target } \\
\text { objective } \\
\text { function }\end{array}$ & $t$-value & $p$-value \\
\hline ESCO & Soil evaporation compensation factor & $\mathrm{d}$ & 8.89 & $2.1 \times 10^{-17}$ \\
\hline GW_DELAY & Groundwater delay time (days) & $\mathrm{d}$ & -7.27 & $1.9 \times 10^{-12}$ \\
\hline SOL_BD & Moist bulk density of soil $\left(\mathrm{g} \mathrm{cm}^{-3}\right)$ & $\mathrm{d}$ & 6.30 & $7.9 \times 10^{-12}$ \\
\hline CN2 & Initial SCS curve number for moisture condition 2 & $\mathrm{~d}$ & -5.56 & $4.9 \times 10^{-8}$ \\
\hline SOL_AWC & Available water storage capacity in soil $\left(\mathrm{mm} \mathrm{H}_{2} \mathrm{O} / \mathrm{mm}\right.$ soil $)$ & $\mathrm{d}$ & -4.39 & $1.5 \times 10^{-5}$ \\
\hline CH_K2 & Effective hydraulic conductivity of the main channel alluvium $\left(\mathrm{mm} \mathrm{h}^{-1}\right)$ & $\mathrm{d}$ & -2.17 & 0.030 \\
\hline REVAPMN & Threshold depth of water in the shallow aquifer for revap to occur (mm) & $\mathrm{d}$ & -2.15 & 0.032 \\
\hline ALPHA_BF & Baseflow alpha factor (days) & $\mathrm{d}$ & 2.96 & 0.0033 \\
\hline GW_REVAP & Groundwater revap coefficient & $\mathrm{d}$ & 2.78 & 0.0057 \\
\hline HVSTI & Harvest index for optimal growing conditions & $\mathrm{s}$ & -28.83 & $6.1 \times 10^{-108}$ \\
\hline HEAT_UNITS & Total heat units for plant to reach maturity (cumulative ${ }^{\circ} \mathrm{C}$ ) & $\mathrm{s}$ & -3.94 & $9.4 \times 10^{-5}$ \\
\hline WSYF & Harvest index for water-stressed growing conditions & $\mathrm{s}$ & -0.84 & 0.40 \\
\hline BIO_E & Radiation use efficiency $\left(\mathrm{g} \mathrm{J} \times 10^{-7}\right)$ & $\mathrm{s}$ & 0.36 & 0.72 \\
\hline HVSTI & Harvest index for optimal growing conditions & $\mathrm{c}$ & -45.57 & $1.7 \times 10^{-178}$ \\
\hline HEAT_UNITS & Total heat units for plant to reach maturity (cumulative ${ }^{\circ} \mathrm{C}$ ) & $\mathrm{c}$ & -21.35 & $5.2 \times 10^{-72}$ \\
\hline AUTO_NYR & Maximum amount of mineral $\mathrm{N}$ application in any one year $\left(\mathrm{kg} \mathrm{Nha}^{-1} \mathrm{yr}^{-1}\right)$ & $\mathrm{c}$ & -9.03 & $3.8 \times 10^{-18}$ \\
\hline BIO_E & Radiation use efficiency $\left(\mathrm{g} \mathrm{J} \times 10^{-7}\right)$ & $\mathrm{c}$ & -2.99 & 0.0030 \\
\hline WSYF & Harvest index for water-stressed growing conditions & $\mathrm{c}$ & -0.56 & 0.58 \\
\hline
\end{tabular}

The objective function $\Phi$ was used to evaluate the performance of each simulation at each discharge station (Krause et al., 2005):

$$
\begin{array}{lll}
\Phi=|b| R^{2} & \text { for } & |b| \leq 1 \\
\Phi=|b|^{-1} R^{2} & \text { for } & |b|>1
\end{array}
$$

where $R^{2}$ is the coefficient of determination (sensu Dalgaard, 2008) and $b$ the slope of the regression line between the simulated and measured data. All discharge stations were conjunctively calibrated with an overall objective function $O$ where each station was weighted equally:

$O=\frac{1}{n} \sum_{i=1}^{n} \Phi_{i}$

where $n$ is the number of stations. The range of $\Phi$ and $O$ is 0 to 1 where 1 indicates a perfect match. The best simulation was considered as the one with the highest $O$ value. It constituted the basis of the input parameter ranges for each subsequent iteration.

The objective function used to evaluate the performance of each simulation with respect to crop yield was the Root Mean Squared Error (RMSE):

$\mathrm{RMSE}=\sqrt{\frac{1}{n} \sum_{i=1}^{n}\left(M_{i}-S_{i}\right)^{2}}$

where $n$ is the number of observations, $M$ is the measured data and $S$ is the simulated data. The range of RMSE is 0 to $\infty$ where 0 is optimal. The best simulation was considered as the one with the lowest RMSE. The crop yield was simulated on each HRU in each season. From this the area-weighted average basin yield was calculated and compared with the CEC provincial-scale data for each agricultural system.

Discharge, smallholder maize yield and commercial maize yield were simultaneously calibrated. No combined objective function between these was defined because of the 
incommensurable nature of maize yield and discharge, and because the two agricultural systems were simulated on independent HRUs with independent parameter groups. For the parameters affecting all output variables, range refinement between iterations considered all objective functions.

In SUFI-2 the entire set of simulations constituting one calibration iteration form the basis of the uncertainty quantification. The range within which $95 \%$ of the output variable values of all simulations fall represents the uncertainty. This is denoted as the $95 \%$ prediction uncertainty band (95PPU). The 95PPU is calculated from the cumulative frequency distribution of all simulation output values for each variable at each point in time. The lower boundary of the 95PPU (L95PPU) reflects the 2.5 percentile, while the upper boundary (U95PPU) reflects the 97.5 percentile of the distribution. The performance of each iteration is evaluated with the $P$ and $R$-factors. The $P$-factor is the fraction of the measured data bracketed by the 95PPU band. It ranges from 0 to 1 where 1 is ideal. The $R$-factor is the average width of the 95PPU band divided by the standard deviation of the measured variable. It ranges from $\infty$ to 0 where 0 is ideal and $<1$ is desirable (Abbaspour et al., 2007). A $10 \%$ measurement error for all observed variables was included in the $P$ and $R$-factor calculations (Butts et al., 2004). A number of calibration iterations were carried out seeking to reach more optimal $P$ - and $R$-factors until a further improvement in one factor was not possible without a deterioration in the other. The last iteration was then taken as the posterior set of parameter ranges on which the subsequent analyses were based.

\subsection{Analysis of smallholder systems and in situ water harvesting}

In this paper we focussed the analysis on the smallholder systems in accordance with the objectives. The crop water productivity (CWP, $\mathrm{kg} \mathrm{m}^{-3}$ ) was derived based on Kijne et al. (2003):

$\mathrm{CWP}=\frac{Y}{E_{T}}$

where $Y$ is the crop yield in the HRU for the season $\left(\mathrm{kg} \mathrm{ha}^{-1}\right)$ and $E_{T}$ is the corresponding seasonal evapotranspiration $\left(\mathrm{m}^{3} \mathrm{ha}^{-1}\right)$. A higher CWP thus constitutes a more water productive agricultural system. Some analysts further separate $E_{T}$ into soil and open water evaporation, evaporation of intercepted water in the canopy foliage as well as transpiration through vegetation (Savenije, 2004). However, we chose to treat them as an aggregated flux in this study for ease of comparison with previous research.

Given that the principal source of water for in situ WH is locally generated surface runoff, the availability of water for in situ WH in smallholder systems was considered to be the annual cumulative generated surface runoff from these HRUs under current management conditions. This can be seen as the upper boundary of water availability for in situ WH tech- niques capturing runoff (see discussion). The supplemental water demand (SWD) was estimated in a separate simulation by allowing automatic irrigation from an unlimited external source onto the smallholder HRUs in response to crop water deficits while holding all other variables constant. The SWD (the applied amount) is the amount of water required - in addition to rainfall - to meet the crop water deficit, and the additional amount of soil evaporation accumulated over the crop-growing season. It thus represents the intended function (soil moisture addition) of the surface runoff captured through in situ WH. The peak SWD is defined as the amount applied when irrigation is induced as soon as there is crop water deficit (i.e. $>0$ water stress). In the SWD simulations, some stresses still remain on the crop (e.g. from plant nutrient deficiencies). Further water demand may therefore arise if these stresses were to be alleviated as well. However, because in situ WH is primarily aimed at addressing the crop water deficits, no further stresses were assumed to be conjunctively alleviated.

The reliability of in situ WH in smallholder systems was estimated as the percentage of years during the simulation period in which the availability of water for in situ WH equalled or exceeded the peak SWD. The correlation between the reliability at the U95PPU boundary and the L95PPU boundary was assessed with Spearman's rank correlation coefficient ( $\rho$, Spearman, 1904). Finally, all HRU level analyses were scaled to sub-basin level as an area-weighted mean for presentation purposes.

\section{Results}

\subsection{Calibration and evaluation}

\subsubsection{Maize yield}

A set of simulations throughout the posterior parameter space were capable of reproducing reported yields in both the calibration and the evaluation periods, respectively (Fig. 2). The $P$-factors were ideal while the $R$-factors were large, indicating that the set of simulations cover the observations well but that they were somewhat blunt in doing so. It is certainly possible to refine the prediction bands further. However, it may result in "overfitting" of the parameters, potentially reducing the predictive power in the evaluation period considerably (Notarnicola et al., 2008). The calibration reduced the width of the predictive uncertainty band (the $R$-factor) for maize yield by $23 \%$. The aggregated smallholder maize yields over the two time-periods were well captured by the best parameterisation. This is demonstrated by the low RMSE and close proximity of the medians in both the calibration period (observed: $0.81 \mathrm{tha}^{-1}$, simulated: $0.83 \mathrm{tha}^{-1}$ ), and the evaluation period (observed: $0.50 \mathrm{tha}^{-1}$, simulated: $0.43 \mathrm{tha}^{-1}$ ). 


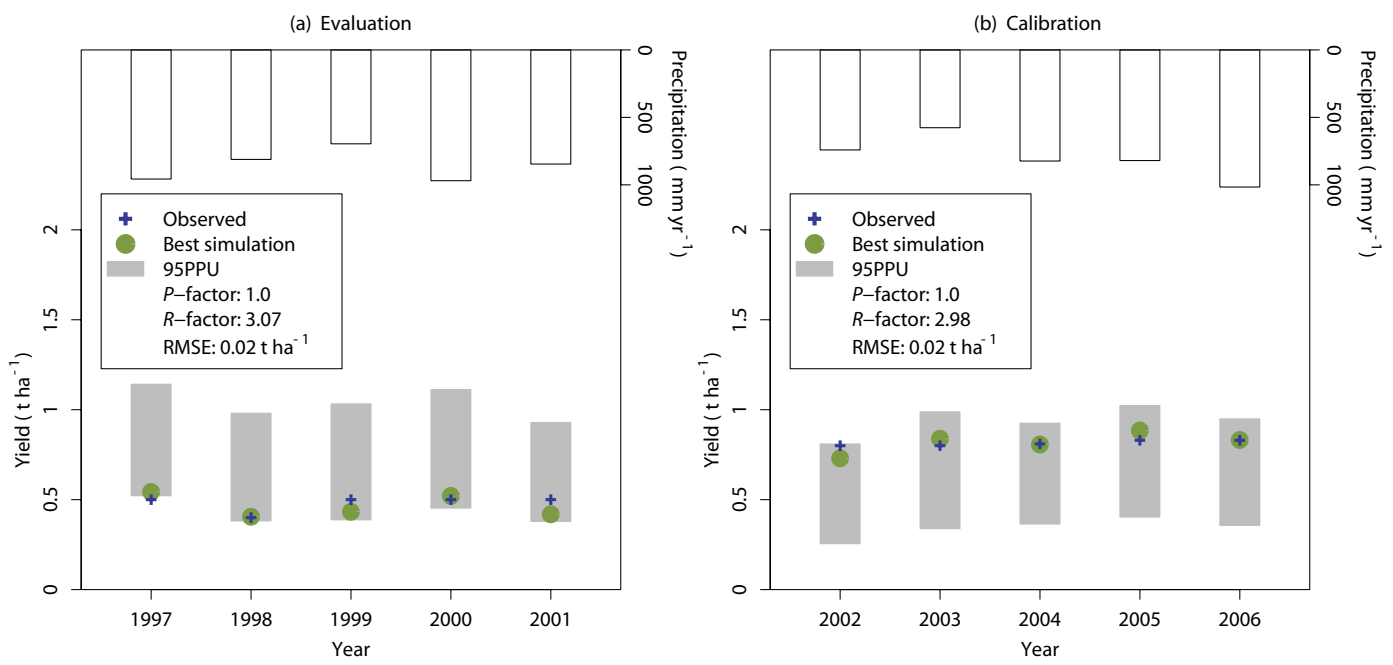

Fig. 2. Observed and simulated annual maize yield in smallholder systems during (a) the evaluation period and (b) the calibration period. RMSE is Root Mean Squared Error - the objective function used to derive the best simulation - and 95PPU represents the 95\% prediction uncertainty band. The basin-average precipitation for each year is presented at the top of the figure.

Table 5. Performance of the model with respect to daily discharge in the calibration (Cal.) and evaluation (Eval.) periods, respectively. The overall weighted objective function $(O)$ was 0.47 for the calibration period and 0.36 for the evaluation period.

\begin{tabular}{|c|c|c|c|c|c|c|c|c|c|}
\hline \multirow{2}{*}{$\begin{array}{l}\text { Discharge } \\
\text { station }\end{array}$} & \multirow{2}{*}{$\begin{array}{l}\text { Drainage Area } \\
\qquad\left(\mathrm{km}^{2}\right)\end{array}$} & \multicolumn{2}{|c|}{$P$-factor } & \multicolumn{2}{|c|}{$R$-factor } & \multicolumn{2}{|c|}{$\Phi$} & \multicolumn{2}{|c|}{$R^{2}$} \\
\hline & & Cal. & Eval. & Cal. & Eval. & Cal. & Eval. & Cal. & Eval. \\
\hline V3H002 & 1518 & 0.34 & 0.47 & 0.89 & 1.37 & 0.85 & 0.42 & 0.63 & 0.43 \\
\hline V3H010 & 5887 & 0.77 & 0.63 & 0.40 & 0.55 & 0.36 & 0.23 & 0.69 & 0.53 \\
\hline V6H003 & 312 & 0.78 & 0.84 & 0.96 & 1.06 & 0.42 & 0.35 & 0.42 & 0.28 \\
\hline V1H001 & 4176 & 0.64 & 0.64 & 0.28 & 0.38 & 0.67 & 0.61 & 0.83 & 0.71 \\
\hline V6H002 & 12862 & 0.62 & 0.57 & 0.48 & 0.61 & 0.68 & 0.73 & 0.77 & 0.72 \\
\hline V1H041 & 434 & 0.46 & 0.32 & 0.32 & 0.32 & 0.32 & 0.23 & 0.65 & 0.53 \\
\hline V7H012 & 196 & 0.70 & 0.59 & 0.65 & 0.60 & 0.16 & 0.18 & 0.45 & 0.32 \\
\hline V2H004 & 1546 & 0.61 & 0.56 & 0.49 & 0.49 & 0.65 & 0.34 & 0.79 & 0.56 \\
\hline V5H002 & 28920 & 0.70 & 0.58 & 0.84 & 0.92 & 0.73 & 0.38 & 0.65 & 0.46 \\
\hline V2H005 & 260 & 0.66 & 0.54 & 0.79 & 0.72 & 0.41 & 0.27 & 0.48 & 0.49 \\
\hline
\end{tabular}

\subsubsection{Discharge}

Tables 5 and 6, and Fig. 3 summarise and exemplify the results of the calibration and evaluation of river discharge. The model performance varies in space and time and certain aspects of the regimes are capture better than others. $\Phi$ is lower in the evaluation period than in the calibration period. However, the overall reduction is only about $20 \%$ suggesting no "overfitting" of the parameters. The coverage of the observed data by the 95PPU band (the $P$-factor) was on the whole satisfactory, although rather low for $\mathrm{V} 3 \mathrm{H} 002$ and $\mathrm{V} 1 \mathrm{H} 041$. A probable cause in the case of $\mathrm{V} 3 \mathrm{H} 002$ is the prevalence of $0 \mathrm{~m}^{3} \mathrm{~s}^{-1}$ observed discharge ( $46 \%$ of the entire simula- tion period) on which the included $10 \%$ measurement error is not effective. In $78 \%$ of the cases, the best simulation had flows of $\leq 1 \mathrm{~m}^{3} \mathrm{~s}^{-1}$ indicating a close proximity to observations nonetheless. Another reason may be erroneous observations, given the difficulty of accurately measuring low discharge fluxes. Inadequate simulation of discharge peaks is less likely to have been the main cause of the low V3H002 $P$-factor (83\% of flows $\geq$ the $95 \%$ percentile of observations were within the 95PPU). The widths of the 95PPU bands (the $R$-factor) were generally narrower than the standard deviation of the measured variable. The calibration reduced the $R$-factor by $25 \%$ on average. Overall there is no indication of bias in the cumulative discharge for either the calibration 
(a) V3H0O2 - Evaluation

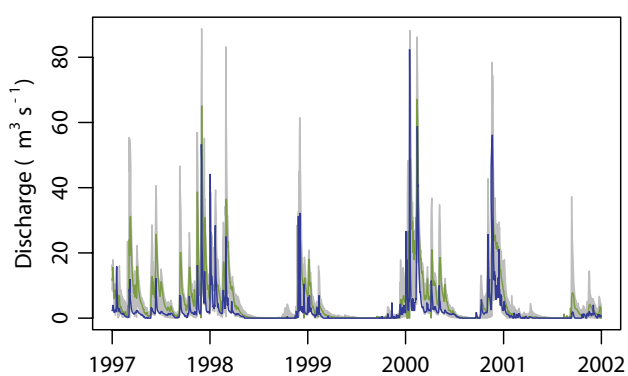

(c) V6H002 - Evaluation

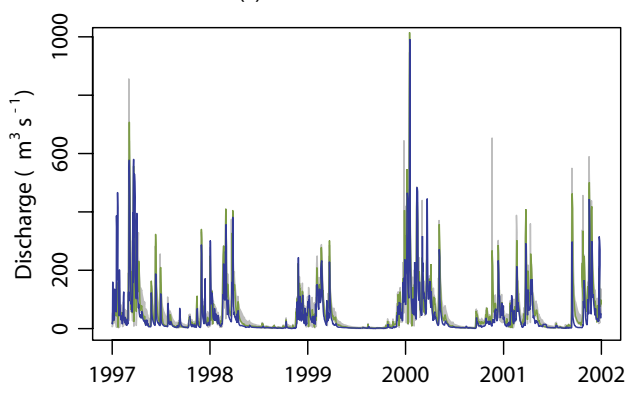

(e) V5H002 - Evaluation

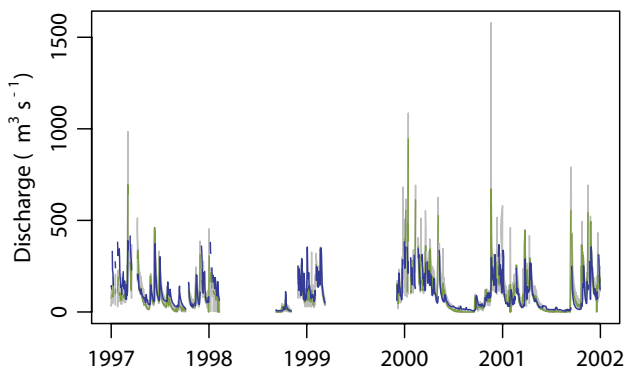

(b) V3H002 - Calibration

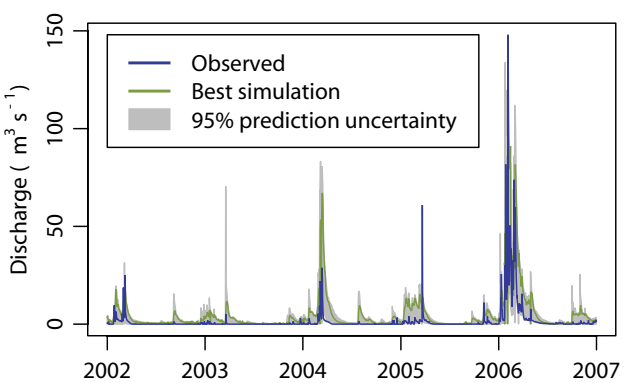

(d) V6H002 - Calibration

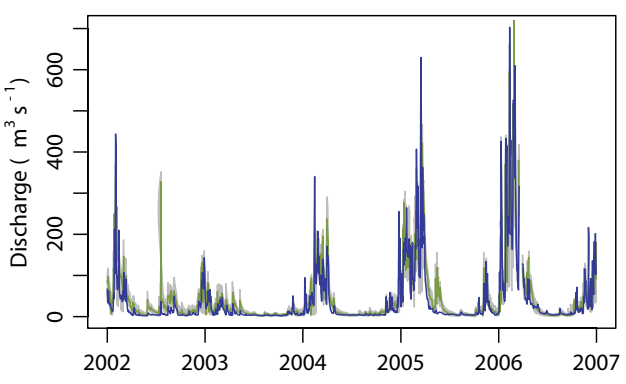

(f) V5H002 - Calibration

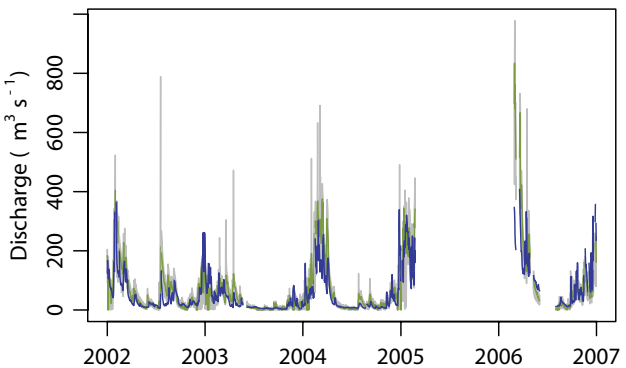

Fig. 3. Observed and simulated daily river discharge for V3H002 (a, b), V6H002 (c, d) and V5H002 (e, f) in the evaluation (a, c, e) and calibration (b, d, f) periods, respectively. The best simulation is the parameter set with the highest objective function $(\Phi)$. Gaps represent missing observations. See Fig. 1 for station locations.

Table 6. Cumulative discharge for all days with observed flow records during the calibration and evaluation periods, respectively $\left(\mathrm{km}^{3}\right.$ per period). U95PPU is the upper boundary and L95PPU is the lower boundary of the 95\% prediction uncertainty band, respectively.

\begin{tabular}{lcccccc}
\hline Discharge station & \multicolumn{3}{c}{ Calibration period } & \multicolumn{3}{c}{ Evaluation period } \\
& Observed & L95PPU & U95PPU & Observed & L95PPU & U95PPU \\
\hline V3H002 & 0.25 & 0.11 & 1.08 & 0.33 & 0.22 & 1.38 \\
V3H010 & 2.19 & 0.41 & 2.77 & 3.02 & 0.69 & 3.51 \\
V6H003 & 0.14 & 0.07 & 0.46 & 0.14 & 0.05 & 0.42 \\
V1H001 & 3.86 & 2.26 & 4.68 & 3.92 & 2.46 & 5.46 \\
V6H002 & 5.85 & 4.09 & 9.69 & 6.85 & 5.23 & 12.72 \\
V1H041 & 1.10 & 0.55 & 1.06 & 1.17 & 0.48 & 0.96 \\
V7H012 & 0.13 & 0.04 & 0.19 & 0.16 & 0.05 & 0.23 \\
V2H004 & 1.03 & 0.57 & 1.39 & 1.71 & 0.57 & 1.70 \\
V5H002 & 6.47 & 4.58 & 11.19 & 9.91 & 6.54 & 14.53 \\
V2H005 & 0.49 & 0.13 & 0.63 & 0.63 & 0.16 & 0.73 \\
\hline
\end{tabular}


or the evaluation period (Table 6). Given the high temporal resolution and the relatively conservative objective function criterion, the overall model performance was adequate for further analysis.

\subsection{Maize yield and crop water productivity}

The smallholder maize yields are rather low in the basin (Fig. 4). Still, there is some degree of spatial differentiation. Areas in the Southwest and South have relatively high yields while areas in the North central and East have lower yields. The connection between parameter values and yields is non-uniform in space. This is exemplified by a set of subbasins in the far West which fell in the same yield category at the U95PPU boundary but in different yield categories at the L95PPU boundary. Of the simulated yield constraints, the soil nitrogen content is the primary regulator of the yield level and spatial variability (median N-stress: 38-77 days $\left.\mathrm{yr}^{-1}, 95 \mathrm{PPU}\right)$. Soil acidity is also known to limit the crop growth in the region (Naramabuye et al., 2008). The results further suggest the temporal yield variability is significantly ( $p$-value: $<2 \times 10^{-16}$ ) related to the variability of soil moisture in the root zone (particularly in 2004), and to temperature stress (especially at high latitudes in combination with high heat unit parameterisations).

The CWP in the smallholder systems is rather low (spatiotemporal median: $\left.0.08-0.22 \mathrm{~kg} \mathrm{~m}^{-3}, 95 \mathrm{PPU}\right)$. Even at the U95PPU boundary, some sub-basins in the East display a CWP value $<0.15 \mathrm{~kg} \mathrm{~m}^{-3}$ (Fig. 4). The spatial pattern varies in concert with the spatial variability in yield and $E_{T}$. In a broad sense there is a meandering belt of sub-basins with low CWP in the central North, East and toward the river mouth; and areas of higher CWP at the higher elevations in the West and North. The temporal variability is often rather small (see supplementary online material: http://www.hydrol-earth-syst-sci.net/13/2329/ 2009/hess-13-2329-2009-supplement.zip). However, a distinct set of HRUs display relatively high CWP values in 1998. This was principally caused by particularly high yields rather than exceptional $E_{T}$ values (Fig. 5), suggesting that increasing yields through WH adoption may also raise CWP.

\subsection{Water availability, demand and reliability of in situ WH in smallholder systems}

\subsubsection{Water availability for in situ WH}

The surface runoff is low within most smallholder HRUs (spatiotemporal median: $0-17 \mathrm{~mm}$ year $^{-1}$, 95PPU). The dominant outflow process is $E_{T}$, both in the smallholder HRUs and in the basin at large, as expected in this climatic zone (Table 7).

The principal areas of relatively high runoff generation are in the headwaters in the West close to the Drakensberg and to some extent in the East toward the river mouth (Fig. 6). The
Table 7. Average annual water balance for the basin. The range indicates the $95 \%$ prediction uncertainty band.

\begin{tabular}{lcc}
\hline Water balance component & $\begin{array}{c}\text { Amount } \\
\left(\mathrm{mm} \mathrm{yr}^{-1}\right)\end{array}$ & Percentage \\
\hline Precipitation & 826 & 100 \\
Evapotranspiration & $620-687$ & $75-83$ \\
Surface runoff & $5-16$ & $1-2$ \\
Lateral flow & $50-93$ & $6-11$ \\
Shallow aquifer return flow & $39-76$ & $5-9$ \\
Deep aquifer recharge & $23-69$ & $3-8$ \\
\hline
\end{tabular}

uncertainty of the runoff generation is rather large, though a large part of the basin consistently displays low runoff amounts throughout the posterior parameter space. The low runoff amounts are particularly related to the high atmospheric evaporative demand and soil moisture deficits in large parts of the basin. At higher altitudes, the precipitation is higher and the temperature lower, leading to lower evaporative demand and higher surface runoff.

The temporal variability at the L95PPU boundary is relatively small, but considerable and complex at the U95PPU boundary (see supplementary online material). At U95PPU, the parameter values render the model sensitive to the temporal dynamics of climate and soil moisture. Such variability is reduced at L95PPU by the parameterisation of the most sensitive parameters affecting surface runoff (Table 4). This highlights both the temporal variability itself but also the large uncertainty with which it is associated. Consequently, the water availability is hard to predict; and relying on it as a base for food production involves considerable risk, a fact also reported for the local scale (de Winnaar et al., 2007).

\subsubsection{Supplemental water demand}

The demand for additional water in smallholder systems is relatively high in the central and eastern parts of the basin (Fig. 7). The high SWD is mainly related to the radiationinduced biomass production potential and the high evaporative demand. Particularly high peak SWD was obtained around Ladysmith, Newcastle, and Utrecht, with a relatively dry climate. The smallholder systems closer to the Drakensberg generally display low peak SWD. The SWD simulations significantly ( $p$-value: $<2 \times 10^{-16}$ ) reduced the water stress on crop growth (range of water stress: $0-134$ days $\mathrm{yr}^{-1}$ for current conditions and 0-9 days $\mathrm{yr}^{-1}$ for the peak SWD scenario at U95PPU). Although the water stress is relieved to a large extent, the results suggest crop growth is still inhibited by e.g. low soil nitrogen content (median $\mathrm{N}$ stress for the SWD scenario: $39-77$ days $\mathrm{yr}^{-1}$, 95PPU).

The temporal variability in SWD is high at the U95PPU boundary but low at the L95PPU boundary (see supplementary online material). It is largely driven by the climate 
(a)

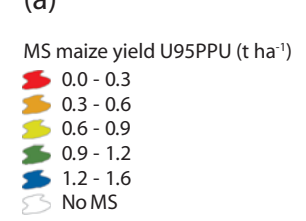

(b)

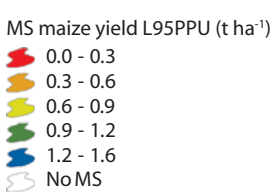

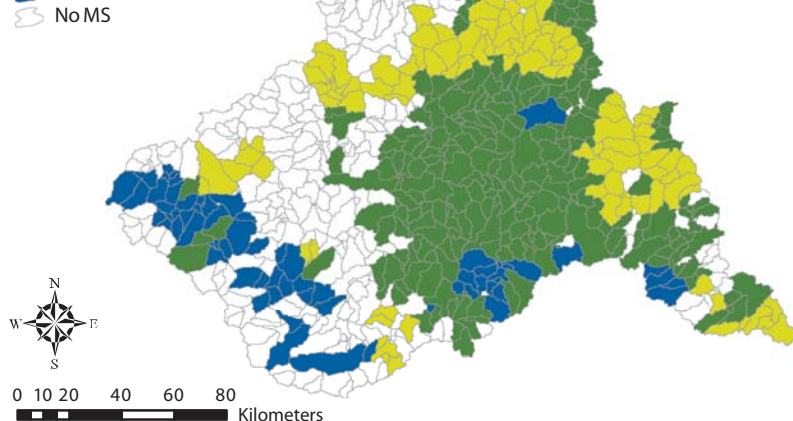

(c)

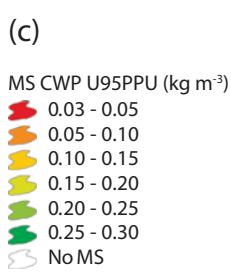

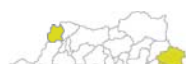

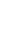

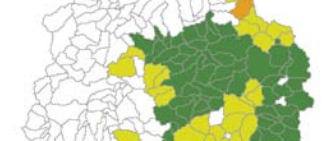

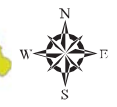
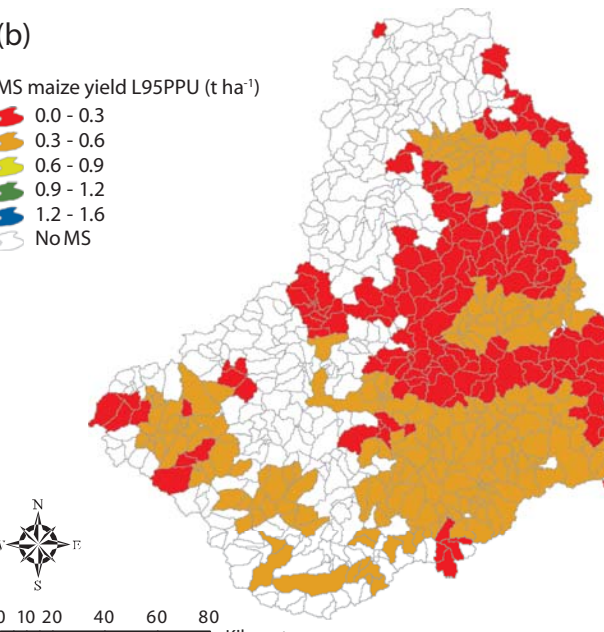

(d)

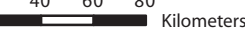

$$
\begin{aligned}
& \text { MS CWP L95PPU }\left(\mathrm{kg} \mathrm{m}^{-3}\right) \\
& 30.03-0.05 \\
& 30.05-0.10 \\
& 0.10-0.15 \\
& 0.15-0.20 \\
& 30.20-0.25 \\
& 3 \text { No MS }
\end{aligned}
$$

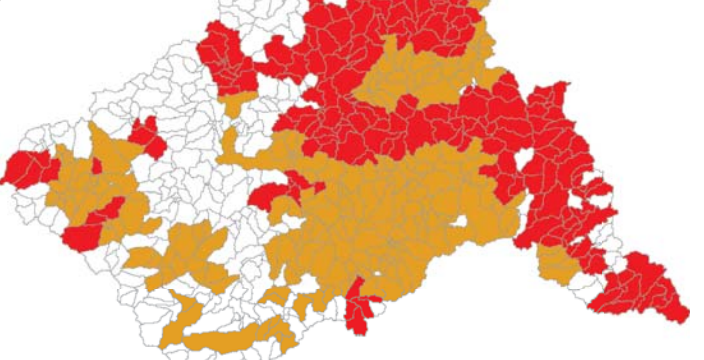

Kilometers

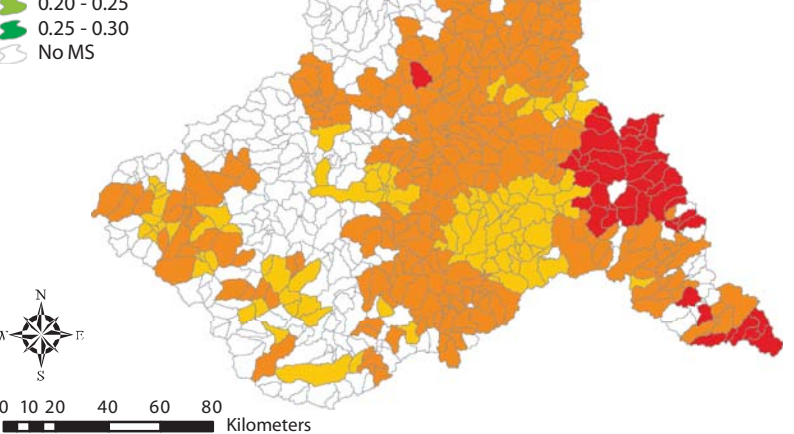

Fig. 4. Median, area-weighted maize yield (a, b) and crop water productivity (CWP), (c, d) in smallholder systems (MS) during the simulation period. U95PPU (a, c) is the upper boundary and L95PPU (b, d) is the lower boundary of the 95\% prediction uncertainty band, respectively. "No MS" indicates sub-basins without the MS class. Projection and Datum as Fig. 1.

dynamics (e.g. variability in evaporative demand and dryspell occurrences) and variable water demands at different stages of the crop growth cycle. The uncertainty is again considerable (spatiotemporal median: $0-113 \mathrm{~mm}$ year $^{-1}$, 95PPU). Nevertheless, the spatial patterns of water availability and demand are relatively consistent and on the whole inversely related - areas of low SWD coincide with the areas of high availability. At the extremes, water is not available where demanded or not demanded where available. It is in the interface between the extremes that WH may fill a gap by bridging some of the crop water deficits. This is illustrated by the intra-seasonal patterns of water availability and SWD at two locations near Weenen and Bergville (Fig. 8). Near Weenen the majority of the seasonal SWD precede the surface runoff, rendering surface runoff capture only marginally efficient. In contrast, near Bergville the runoff generally precede the SWD, enabling timely soil moisture enhancement.

\subsubsection{Reliability of in situ WH}

Given the risks associated with the inter-annual variability in both the water availability for in situ WH and the SWD in smallholder systems, it is pertinent with an analysis of the reliability of in situ WH technologies (Fig. 9). The reliability of in situ WH is particularly high in the Southwest toward the Drakensberg, and to some extent in the Southeast and toward the river mouth. The reliability is low in the majority of sub-basins along a North-South transect through the basin. The reliability patterns are closely related to the spatial variations in precipitation, temperature, and atmospheric evaporative demand. This spatial differentiation highlights the importance of geographically explicit reliability estimates. For example, in situ WH investment appears to involve considerably greater risk around Weenen than around Bergville. 

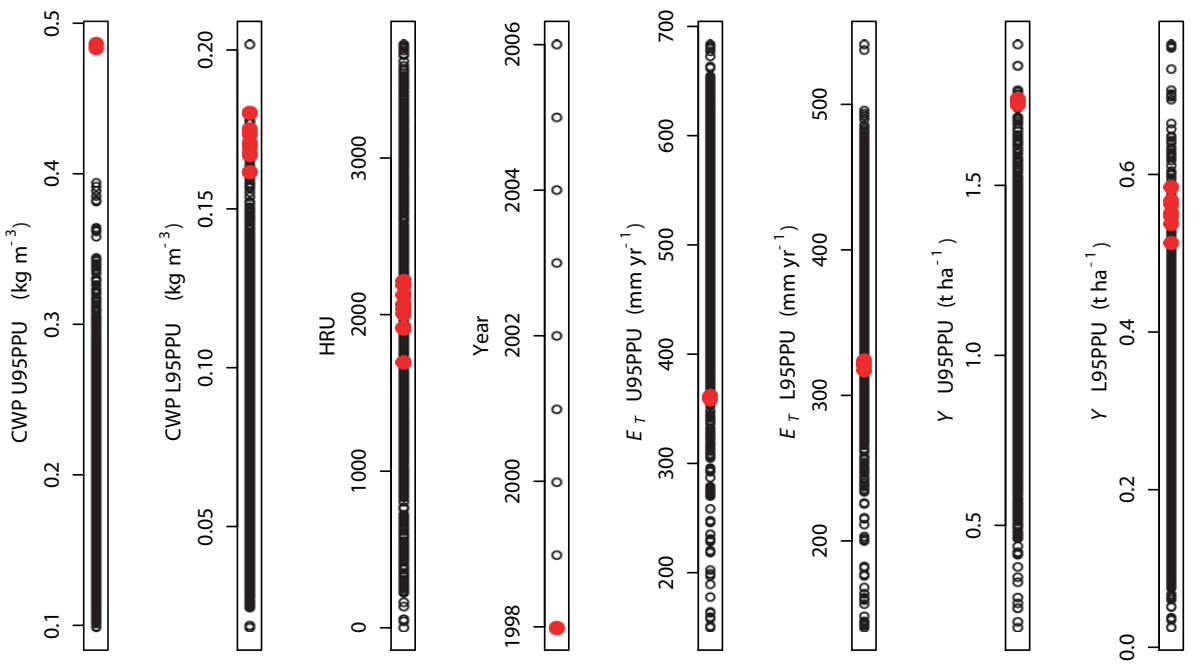

Fig. 5. Parallel coordinate plot of crop water productivity (CWP) in smallholder systems against space (HRU), time (Year), evapotranspiration $\left(E_{T}\right)$ and maize yield $(Y)$ for the upper (U95PPU) and lower (L95PPU) 95\% prediction uncertainty boundaries, respectively. Red items are the space-time combinations with relatively high $\mathrm{CWP}\left(>0.4 \mathrm{~kg} \mathrm{~m}^{-3}\right.$, U95PPU).

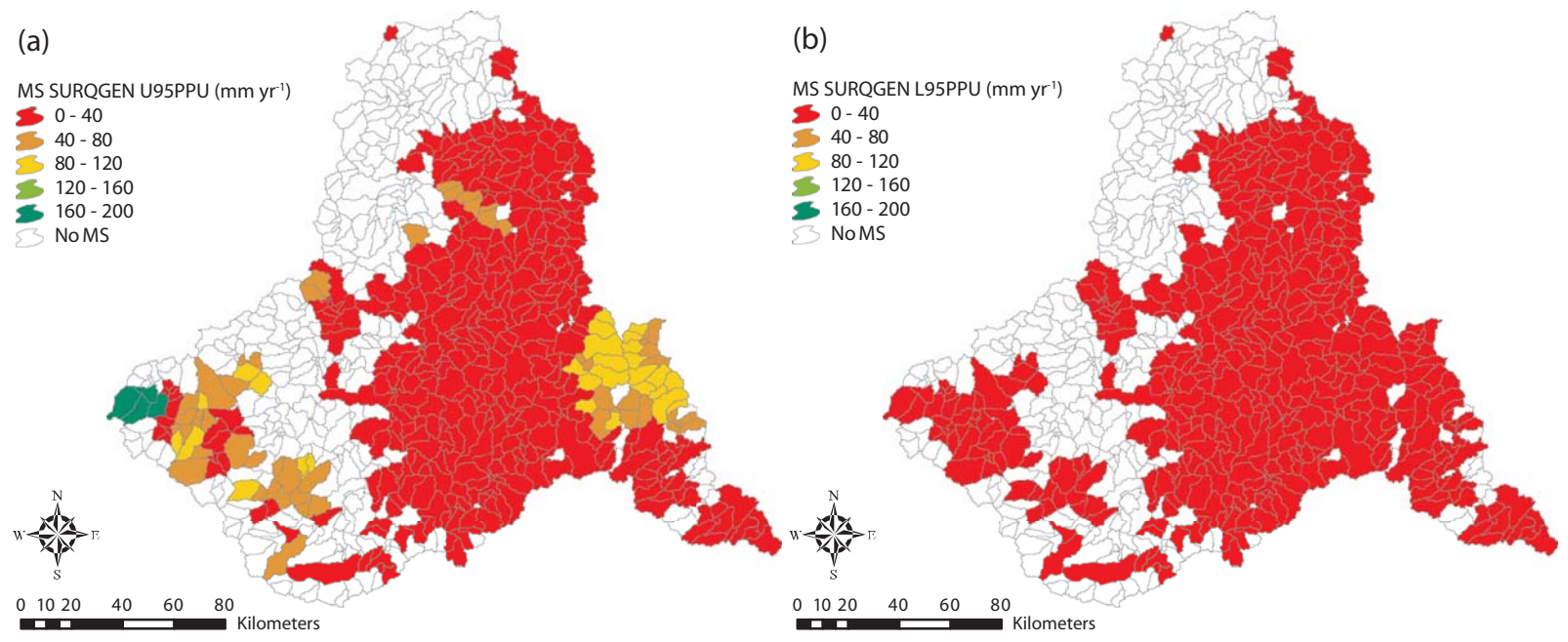

Fig. 6. 1997 to 2006 median annual generated surface runoff (SURQGEN) from the smallholder agricultural production land use class (MS), area-weighted to sub-basin level. U95PPU (a) is the upper boundary and L95PPU (b) is the lower boundary of the 95\% prediction uncertainty band, respectively. "No MS" indicates sub-basins without the MS class. Projection and Datum as Fig. 1.

The similarity of the reliability throughout the posterior parameter space $(\rho=0.78)$ indicates a relatively high confidence in the reliability estimate. In certain areas the reliability is somewhat higher at the L95PPU boundary relative to the U95PPU boundary (e.g. between Newcastle and Utrecht). However, in the majority of sub-basins an indifferent or reverse relationship was found. Although parameter uncertainty affects the magnitude of the water availability and SWD, the effect on the temporal patterns is relatively small such that the climatic variability signal dominates the reliability results.
The reliability represents the convergence of water availability for in situ WH and SWD in smallholder systems in space and time. Along with a set of other factors, these influence the suitability of in situ WH. If the reliability alone is taken as an indicator of the suitability of in situ $\mathrm{WH}$, then the potentially suitable areas for in situ WH at any given risk level can be derived. Based on that premise, Table 8 presents the cumulative area and percentage of smallholder HRUs potentially suitable for in situ WH relative to a set of system reliability levels. At an inconceivably high risk level of $10 \%$ reliability, less than $50 \%$ of the smallholder HRUs appear to be suitable for in situ WH from a water availability and 
(a)

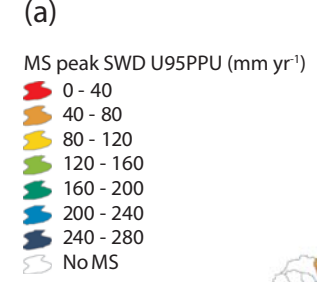

(b)

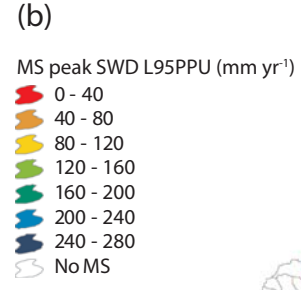

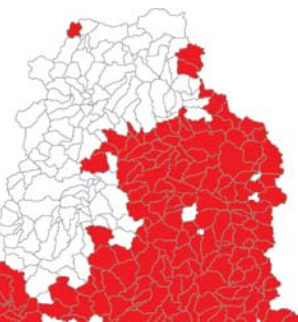

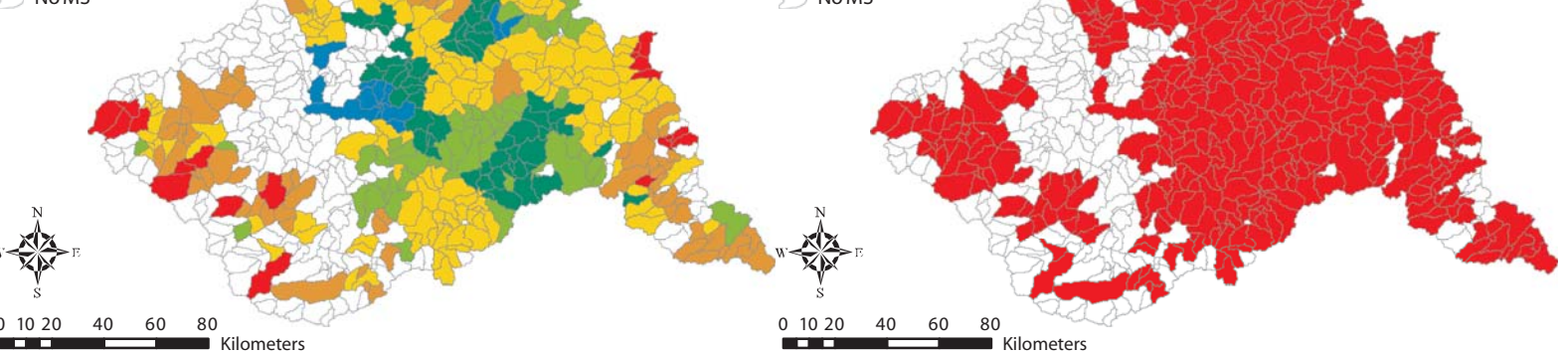

Fig. 7. 1997 to 2006 median annual peak supplemental water demand (SWD) in the smallholder agricultural production land use class (MS), area-weighted to sub-basin level. U95PPU (a) is the upper boundary and L95PPU (b) is the lower boundary of the 95\% prediction uncertainty band, respectively. "No MS" indicates sub-basins without the MS class. Projection and Datum as Fig. 1.

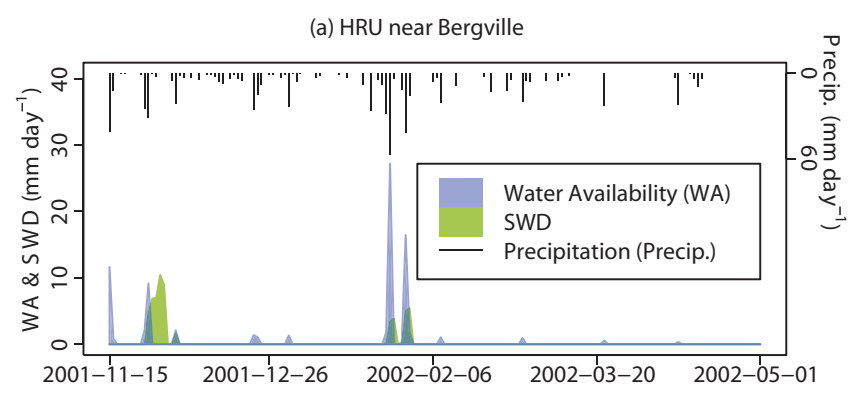

(b) HRU near Weenen

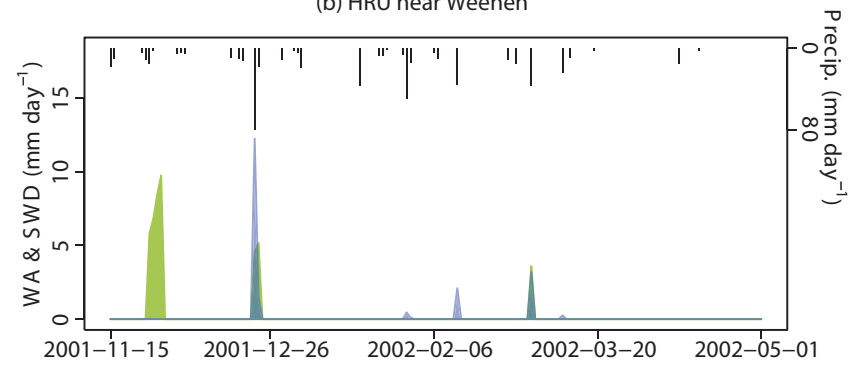

Fig. 8. Daily water availability (WA), peak supplemental water demand (SWD) and precipitation (Precip.) during the 2001-2002 smallholder cropping season for a smallholder HRU near (a) Bergville (reliability $=50-60 \%, 95 \mathrm{PPU}$ ) and (b) Weenen (reliability $=10-20 \%, 95 \mathrm{PPU}$ ). The daily range represents the $95 \%$ prediction uncertainty band (95PPU) for WA and SWD. demand perspective. At the $75 \%$ reliability level, adoption of in situ WH may still be an attractive strategy in approximately 7000 to 9000 ha (4-5\%) of the smallholder lands.

\section{Discussion}

\subsection{Simulation performance}

Simulations of agro-hydrological systems are challenging. The challenges include: data quality and resolution; uncertainty in the process understanding, model structure and parameterisation; and conditionality of the results on the type of uncertainty evaluation procedure utilised (Beven, 1993; Abbaspour and Johnson, 2004). Uncertainties were explicitly accounted for here to improve the transparency of the results to such challenges.

The uncertainty bands of the maize yield simulations are relatively wide, reflecting the uncertainty of the model structure and the input data. Structural simplifications include lack of biodiversity, competition, and soil acidity considerations. Input data uncertainty originate from e.g. the coarse resolution of the fertiliser and soil data, the scant availability of information on management practices, and the scale difference between the CEC yield estimate (KwaZulu-Natal province, $92100 \mathrm{~km}^{2}$ ) and the simulated area (Thukela basin, $29000 \mathrm{~km}^{2}$ ). However, the best parameterisation is satisfactorily able to capture the reported maize yields (RMSE $0.02 \mathrm{tha}^{-1}$, i.e. $2 \%$ and $4 \%$ of mean reported maize yield for the calibration and evaluation periods, respectively). The reduced performance of the model in the evaluation period may be explained by the roughness of the CEC estimate of smallholder maize yields (based on information averaged 
Table 8. Cumulative area and percent of smallholder HRUs potentially suitable for in situ WH at different reliability levels (i.e. smallholder HRUs with reliability equal to or above the given reliability level). U95PPU is the upper boundary and L95PPU is the lower boundary of the $95 \%$ prediction uncertainty band, respectively.

\begin{tabular}{cccccc}
\hline \multirow{2}{*}{$\begin{array}{c}\text { Reliability } \\
\text { level (\%) }\end{array}$} & \multicolumn{2}{c}{ Area (ha) } & & \multicolumn{2}{c}{ Percent } \\
\cline { 2 - 3 } \cline { 5 - 6 } \cline { 5 - 6 } & U95PPU & L95PPU & & U95PPU & L95PPU \\
\hline 10 & 81057 & 73220 & & 44 & 40 \\
25 & 52604 & 37188 & & 28 & 20 \\
50 & 24282 & 30499 & & 13 & 16 \\
75 & 9421 & 6721 & & 5 & 4 \\
90 & 4450 & 4917 & & 2 & 3 \\
\hline
\end{tabular}

to $10000 \mathrm{~s}$ of hectares and $1000 \mathrm{~s}$ of tons). Krysanova et al. (1998), Krysanova et al. (1999), and Wechsung et al. (2000) have evaluated the model's performance against observed maize, wheat, barley, and potato yields on district level in Germany. Similarly to our best parameterisation, they found a good agreement between observed and simulated yields on average-annual resolution ( $6 \%$ lower than observed for maize).

The large uncertainty of our maize yield results provides impetus for further model refinement and improved evaluation. Given the sensitivity of the crop yield to harvest index alterations (Table 4), refinement of the harvest index equations are likely to reduce the uncertainty. Luo et al. (2008) suggested that sensitising the harvest index to varying water and nutrient stress during different phenological stages may aid in this pursuit. Including additional plant growth constraints (e.g. soil acidity, weed infestation, and plant diseases), and a dynamically joined constraint module may help to differentiate between various sources of uncertainty. Aside from model conceptual improvements, it is critical to improve the input and evaluation databases to further reduce the uncertainty. Key here is better knowledge of local cultivar types (e.g. biomass development profiles, harvest indices) and management practices (e.g. spatiotemporal cultivar distributions and timing of operations), as well as more precise yield observations, systematically collected and representative of a given area.

Certain aspects of the discharge results also leave room for further improvement. In some cases the recession of the peak flow was not as fast as in the observations, possibly caused by inadequate simulation of soil processes (e.g. soilgroundwater interactions, cf. V3H002). Occasionally the reverse was observed (e.g. V1H041). In some instances discharge peaks were present in the simulations but not in the observed data (e.g. V2H004). Performance generally appeared to decrease proportionally with drainage area (Table 5). Possible causes include the coarser scale of the input data relative to the drainage area for small catchments, or simplification of hydrological processes that may be more important on the local scale.

The model performance criteria may be elevated at observation stations just downstream of reservoirs with included outflow records. This does not indicate a real performance improvement because the proximity renders the stations essentially indifferent to varying process parameterisations in the rest of the basin. To minimise this effect, stations close to, or with clear flow-record impacts from reservoirs were here excluded.

The predictive power was reduced by the presence of missing data in the flow records, particularly on peak flows (e.g. V5H002 - the Thukela Mouth at Mandini). The Mandini flow record contains a disproportionately high level of missing data for high flows because of the inability of the weir to monitor flows above $457 \mathrm{~m}^{3} \mathrm{~s}^{-1}$. This may bias the calibration toward lower flows. The bias was here counterbalanced by conjunctively calibrating all discharge stations. Occasional over-prediction of the peaks at this station may hence be nearer to the historical reality than the flow record suggests. This hypothesis could only be tested if discharge data above $457 \mathrm{~m}^{3} \mathrm{~s}^{-1}$ were available.

\subsection{Crop water productivity}

Field-scale studies in the region substantiate the CWP results obtained in this study. In a field trial in the headwaters of the Thukela basin, Kosgei et al. (2007) measured seasonal $E_{T}$ and maize yield in a conventional tillage smallholder system resulting in a CWP of ca $0.4 \mathrm{~kg} \mathrm{~m}^{-3}$ during 20052006. The median CWP values obtained here are somewhat lower (probably related to seasonal fluctuations and the temporal averaging). However, around $2 \%$ of the smallholder HRUs did have similar CWP values in 2005-2006 (0.3$0.4 \mathrm{~kg} \mathrm{~m}^{-3}$ ); of which some correspond to the area of their field trial near Bergville (Fig. 1). Kosgei et al. (2007) measured $E_{T}$ to be $92 \%$ of the rainfall input during the cropgrowing season. The equivalent simulated values during the particular season of their trial correspond satisfactorily (7698\%, 95PPU). Rockström and Barron (2007) reviewed a set of field-scale studies of water productivity in the savannah biome in Eastern and Southern Africa with low CWP values at low yields $\left(0.05-0.6 \mathrm{~kg} \mathrm{~m}^{-3}\right.$ for yields $\left.<0.3-2 \mathrm{tha}^{-1}\right)$. These data agree rather well with the results obtained here (Fig. 4).

A number of factors contribute to the low CWP. The $E_{T}$ is closely coupled with the climatic setting of the basin, and also influenced by residue management (Prihar et al., 1996; Klocke et al., 2009). The maize yield is limited primarily by low soil fertility but also by low soil moisture availability, which is in line with field-scale research in other areas of SSA (e.g. Burkina Faso, Fox and Rockström, 2003). This provides impetus for efforts aimed at raising the soil fertility and the soil water availability. 


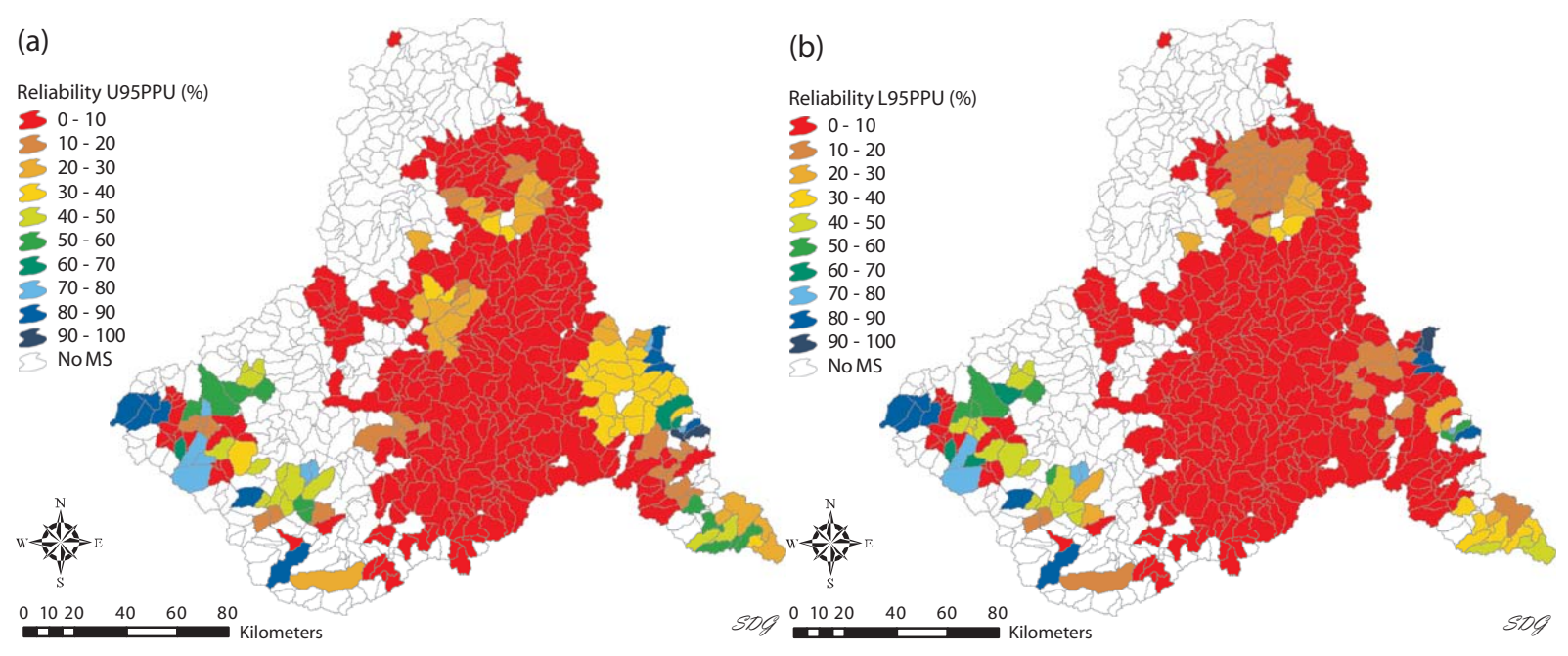

Fig. 9. Reliability of in situ WH in the smallholder agricultural production land use class (MS), area-weighted to sub-basin level. U95PPU (a) is the upper boundary and L95PPU (b) is the lower boundary of the 95\% prediction uncertainty band, respectively. "No MS" indicates sub-basins without the MS class. Projection and Datum as Fig. 1.

\subsection{Reliability and suitability of in situ WH}

In this study we considered the entire amount of generated surface runoff within the smallholder lands as the water available for in situ WH (Fig. 6). In practice, the entire runoff depth will not be available for use since the efficiency in runoff capture, storage, and application is often less than $100 \%$. Kosgei et al. (2007) noted a seasonal runoff reduction of ca. $30 \%$ at a field trial of conservation tillage vs. conventional tillage cultivation. Hence, the water availability component of the reliability may be an overestimate of the practicably available water. It could, however, be enhanced if measures to reduce soil evaporation and increase transpiration (e.g. mulching) can be made practicably available, tapping into the considerably larger $E_{T}$ flows. In this study it was considered more appropriate to regard the entire runoff amount as the available resource in order to reflect the dominant WH types used, and the reliability at the upper boundary of their water availability potential.

The reliability was here calculated based on the peak SWD (Fig. 7). It reflects a condition where crop water deficits are met to their full extent (holding other variables constant). This may not necessarily be required for improved yields or CWP, particularly if relatively short dry spells limit the crop growth. Significantly higher yields may potentially be obtained from lower amounts than peak SWD. Therefore, the reliability estimate is rather conservative from the water demand perspective. In future studies we aim to explore how much of the available water in situ WH may utilise, and to what extent this meets the crop water deficits, which may potentially translate to higher yields and CWP.
The reliability of in situ WH is generally low in the basin, but considerable differences exist between different areas (Fig. 9). Which areas to consider suitable for in situ WH depend on the willingness of risk acceptance of the decisionmakers. The implications of explicitly accounting for the level of risk can be seen in Table 8 . We consider such a risk account to be more useful than the customary assumptions of fixed risk levels. Research in East Africa has highlighted the sensitivity of farmers to such risks (Hatibu et al., 2000). Hence, promotion of WH in the basin and in similar environments elsewhere may more effectively influence the adoption mechanisms if risk accounts - and strategies to estimate and reduce them - are explicitly included.

In this study, the reliability was taken as an indicator of the suitability of in situ WH. In reality, suitability is much more complex than merely a question of water availability and water demand. Factors such as legal rights to water, economic ability to invest in new technologies and safety mechanisms (e.g. reservoirs and fences), financial viability of the production systems, cultural preferences and social norms, complementary livelihood strategies etc., are of prime importance for actual implementation (Woyessa et al., 2006; de Winnaar et al., 2007; Kahinda et al., 2008). However, the mechanistic understanding of the interactions between the various factors is not yet clear, and the associated databases are not available so far. Therefore, these factors were not included in the present analysis. Future suitability assessments may be further refined when the necessary information at various scales becomes available.

Just as Kumar et al. (2006) found, it is the smallholder areas in the headwaters and close to the river mouth that display the highest reliability. Potential hydrological impacts of in situ WH adoption in either of these areas may differ. 
Adoption in the headwaters may affect water availability for downstream reservoirs or aquatic ecosystems if WH alters river discharge. Adoption close to the river mouth may have less impact if beneficiaries are upstream of the implementation areas. Clearly, the potential effects of in situ WH depend on the location and sensitivity of the beneficiaries, and on the spatial reach of these effects.

Given the capacity of the model to simulate hydrological and crop-growth processes, this study provides a foundation for further research. Here we present one application concerning the reliability of in situ WH. Further work could aim at reducing the prediction uncertainty or explore potential effects of WH on crop yield, CWP, and discharge. Such knowledge can be used to inform management strategies aimed at enhancing food and livelihood security.

Acknowledgements. The authors are grateful for the insightful and valuable discussions, and warm hospitality of V. Chaplot, G. de Winnaar, M. Horan, V. M. Kongo, J. R. Kosgei, S. A. Lorentz and R. E. Schulze at the University of KwaZulu-Natal, South Africa, which facilitated this research. B. Wehrli and K. C. Abbaspour are also acknowledged for their continuous interest in and support of this research. Three anonymous reviewers provided helpful suggestions on an earlier draft of this manuscript.

Edited by: E. Toth

\section{References}

Abbaspour, K. C. and Johnson, A. C.: Estimating uncertain flow and transport parameters using a sequential uncertainty fitting procedure, Vadose Zone J., 3, 1340-1352, 2004.

Abbaspour, K. C., Yang, J., Maximov, I., Siber, R., Bogner, K., Mieleitner, J., Zobrist, J., and Srinivasan, R.: Modelling hydrology and water quality in the pre-alpine/alpine Thur watershed using SWAT, J. Hydrol., 333, 413-430, 2007.

Ali, A., Oweis, T., Rashid, M., El-Naggar, S., and Aal, A. A.: Water harvesting options in the drylands at different spatial scales, Land Use and Water Resources Research, 7, 1-13, 2007.

ARC: Mielie-Inligtingsgids - Maize Information Guide, Agricultural Research Council (ARC) - Grain Crops Institute, Potchefstroom, South Africa, 180 pp., 2008.

Arnold, J. G., Srinivasan, R., Muttiah, R. S., and Williams, J. R.: Large area hydrologic modeling and assessment - Part 1: Model development, J. Am. Water Resour. As., 34, 73-89, 1998.

Beven, K.: Prophecy, Reality and Uncertainty in Distributed Hydrological Modeling, Adv. Water Resour., 16, 41-51, 1993.

Bouraoui, F., Benabdallah, S., Jrad, A., and Bidoglio, G.: Application of the SWAT model on the Medjerda river basin (Tunisia), Phys. Chem. Earth, 30, 497-507, 2005.

Butts, M. B., Payne, J. T., Kristensen, M., and Madsen, H.: An evaluation of the impact of model structure on hydrological modelling uncertainty for streamflow simulation, J. Hydrol., 298, 242-266, 2004.

Cleveland, W. S., Grosse, E., and Shyu, W. M.: Chapter 8 - Local regression models, in: Statistical Models in S, edited by:
Chambers, J. M. and Hastie, T. J., Wadsworth\&Brooks/Cole Advanced Books\&Software, Pacific Grove, California, USA, 309376, 1992.

CSIR, ARC, SANDF, DWAF, DoA, and DEA\&T: Updated South African National Land Cover 2000 dataset http://www.agis.agric. za, CSIR, ARC, SANDF, DWAF, DoA and DEA\&T, access: 12 March 2009.

Dalgaard, P.: Introductory Statistics with R, Statistics and Computing Series, 2nd edn., edited by: Chambers, J., Hand, D., and Härdle, W., Springer, New York, USA, 363 pp., 2008.

de Winnaar, G., Jewitt, G. P. W., and Horan, M.: A GIS-based approach for identifying potential runoff harvesting sites in the Thukela River basin, South Africa, Phys. Chem. Earth, 32, 1058 1067, 2007.

$\mathrm{du}$ Toit, W.: Production of maize in the summer rainfall area, Agricultural Research Council - Grain Crops Institute, Potchefstroom, South Africa, 97 pp., 1999.

Falkenmark, M. and Rockström, J.: Balancing water for humans and nature the new approach in ecohydrology, Earthscan, London, UK, 247 pp., 2004.

FAO: The digital soil map of the world and derived soil properties, CD-ROM, 3.5 ed., Food and Agriculture Organization of the United Nations (FAO), Rome, Italy, 1995.

FAO: Training course on water harvesting, FAO Land and Water Digital Media Series - CD-ROM No. 26, Food and Agriculture Organization of the United Nations (FAO), Rome, Italy, 2003.

FAO: Irrigation in Africa in figures, AQUASTAT Survey - 2005, Food and Agriculture Organization of the United Nations (FAO), Rome, Italy, FAO Water Reports, 29, 633 pp., 2005.

FAO: Food Security Statistics of the FAOSTAT Database: http:// www.fao.org/faostat/foodsecurity/index_en.htm, Food and Agriculture Organization of the United Nations (FAO), access: 20 February 2009.

Faramarzi, M., Abbaspour, K. C., Schulin, R., and Yang, H.: Modelling blue and green water resources availability in Iran, Hydrol. Process., 23, 486-501, 2009.

Fox, P. and Rockström, J.: Supplemental irrigation for dry-spell mitigation of rainfed agriculture in the Sahel, Agr. Water Manage., 61, 29-50, 2003.

Gassman, P. W., Reyes, M. R., Green, C. H., and Arnold, J. G.: The soil and water assessment tool: Historical development, applications, and future research directions, T. Asabe, 50, 1211-1250, 2007.

Gurtner, M., Zewenghel, G., Eyassu, H., Zerai, T., Hadgu, Y., Stillhardt, B., and Roden, P.: Land Management in the Central Highlands of Eritrea. A Participatory Appraisal of Conservation Measures and Soils in Afdeyu and its Vicinity, Geographica Bernesia, Bern, Switzerland, 204 pp., 2006.

Hatibu, N., Mahoo, H. F., and Kajiru, G. J.: The role of RWH in agriculture and natural resources management: from mitigating droughts to preventing floods, in: Rainwater Harvesting for Natural Resources Management: A planning guide for Tanzania, edited by: Hatibu, N. and Mahoo, H. F., Regional Land Management Unit (RELMA), Swedish International Development Cooperation Agency (Sida), Nariobi, Kenya, 144 pp., 2000.

Hensley, M., Le Roux, P. A. L., Gutter, J., and Zerizghy, M. G.: A procedure for an improved soil survey technique for delineating land suitable for rainwater harvesting, Water Research Commission, Gezina, South Africa, WRC Report No TT 311/07, 113 pp., 
2007.

Holvoet, K., van Griensven, A., Seuntjens, P., and Vanrolleghem, P. A.: Sensitivity analysis for hydrology and pesticide supply towards the river in SWAT, Phys. Chem. Earth, 30, 518-526, 2005.

Jewitt, G.: Integrating blue and green water flows for water resources management and planning, Phys. Chem. Earth, 31, 753$762,2006$.

Kahinda, J. M., Lillie, E. S. B., Taigbenu, A. E., Taute, M., and Boroto, R. J.: Developing suitability maps for rainwater harvesting in South Africa, Phys. Chem. Earth, 33, 788-799, 2008.

Kijne, J. W., Barker, R., and Molden, D. (Eds.): Water productivity in agriculture: limits and opportunities for improvement, Comprehensive Assessment of Water Management in Agriculture Series 1, CABI Publishing, Wallingford, UK, 354 pp., 2003.

Klocke, N. L., Currie, R. S., and Aiken, R. M.: Soil Water Evaporation and Crop Residues, T. Asabe, 52, 103-110, 2009.

Kongo, V. M. and Jewitt, G. P. W.: Preliminary investigation of catchment hydrology in response to agricultural water use innovations: A case study of the Potshini catchment - South Africa, Phys. Chem. Earth, 31, 976-987, 2006.

Kongo, V. M., Kosgei, J. R., Jewitt, G. P. W., and Lorentz, S. A.: Establishment of a catchment monitoring network through a participatory approach in a small rural catchment in South Africa, Hydrol. Earth Syst. Sci. Discuss., 4, 3793-3837, 2007, http://www.hydrol-earth-syst-sci-discuss.net/4/3793/2007/.

Kosgei, J. R., Jewitt, G. P. W., Kongo, V. M., and Lorentz, S. A.: The influence of tillage on field scale water fluxes and maize yields in semi-arid environments: A case study of Potshini catchment, South Africa, Phys. Chem. Earth, 32, 1117-1126, 2007.

Kosugi, K.: General model for unsaturated hydraulic conductivity for soils with lognormal pore-size distribution, Soil Sci. Soc. Am. J., 63, 270-277, 1999.

Krause, P., Boyle, D. P., and Bäse, F.: Comparison of different efficiency criteria for hydrological model assessment, Adv. Geosci., 5, 89-97, 2005, http://www.adv-geosci.net/5/89/2005/.

Krysanova, V., Muller-Wohlfeil, D. I., and Becker, A.: Development and test of a spatially distributed hydrological water quality model for mesoscale watersheds, Ecol. Model., 106, 261-289, 1998.

Krysanova, V., Wechsung, F., Becker, A., Poschenrieder, W., and Gräfe, J.: Mesoscale ecohydrological modelling to analyse regional effects of climate change, Environ. Model. Assess., 4, 259-271, 1999.

Kumar, M. D., Ghosh, S., Patel, A., Singh, O. P., and Ravindranath, R.: Rainwater harvesting in India: some critical issues for basin planning and research, Land Use and Water Resources Research, 6, 1-17, 2006.

Lehner, B., Verdin, K., and Jarvis, A.: HydroSHEDS Technical Documentation: http://hydrosheds.cr.usgs.gov World Wildlife Fund US, Washington, DC, USA, access: 12 March 2009.

Lenhart, T., Eckhardt, K., Fohrer, N., and Frede, H. G.: Comparison of two different approaches of sensitivity analysis, Phys. Chem. Earth, 27, 645-654, 2002.

Liu, J. G., Fritz, S., van Wesenbeeck, C. F. A., Fuchs, M., You, L. Z., Obersteiner, M., and Yang, H.: A spatially explicit assessment of current and future hotspots of hunger in Sub-Saharan Africa in the context of global change, Global Planet. Change, 64, 222$235,2008$.
Liu, J. G.: A GIS-based tool for modelling large-scale crop-water relations, Environ. Modell. Softw., 24, 411-422, 2009.

Luo, Y., He, C. S., Sophocleous, M., Yin, Z. F., Ren, H. R., and Zhu, O. Y.: Assessment of crop growth and soil water modules in SWAT2000 using extensive field experiment data in an irrigation district of the Yellow River Basin, J. Hydrol., 352, 139-156, 2008.

Lynch, S. D.: Development of a Raster Database of Annual, Monthly and Daily Rainfall for Southern Africa., Water Research Commission, Pretoria, South Africa, WRC Report 1156/1/03, 78 pp., 2003.

Ma'ali, S. H., Bruwer, D. d. V., and Prinsloo, M. A.: Maize National Cultivar Trials - 2004/05-2006/07 - Eastern Areas, Agricultural Research Council - Grain Crops Institute, Potchefstroom, South Africa, 66 pp., 2007.

Makurira, H., Savenije, H. H. G., Uhlenbrook, S., Rockström, J., and Senzanje, A.: Investigating the water balance of on-farm techniques for improved crop productivity in rainfed systems: A case study of Makanya catchment, Tanzania, Phys. Chem. Earth, 34, 93-98, 2009.

Mati, B., De Bock, T., Malesu, M., Khaka, E., Oduor, A., Nyabenge, M., and Oduor, V.: Mapping the potentials for Rainwater Harvesting technologies in Africa: A GIS overview on development domains for the continent and ten selected countries, World Agroforestry Centre (ICRAF), Netherlands Ministry of Foreign Affairs, Nairobi, Kenya, Technical Manual No. 6, 116 pp., 2006.

Mbilinyi, B. P., Tumbo, S. D., Mahoo, H. F., and Mkiramwinyi, F. O.: GIS-based decision support system for identifying potential sites for rainwater harvesting, Phys. Chem. Earth, 32, 10741081, 2007.

Molden, D. (Ed.): Water for Food, Water for Life: A Comprehensive Assessment of Water Management in Agriculture, Earthscan, London, UK, 688 pp., 2007.

Muleta, M. K. and Nicklow, J. W.: Sensitivity and uncertainty analysis coupled with automatic calibration for a distributed watershed model, J. Hydrol., 306, 127-145, 2005.

Naramabuye, F. X., Haynes, R. J., and Modi, A. T.: Cattle manure and grass residues as liming materials in a semi-subsistence farming system, Agr. Ecosyst. Environ., 124, 136-141, 2008.

NCSC: Crop field boundaries: http://www.siq.co.za, National Crop Statistics Consortium of South Africa (NCSC), access: 12 March 2009.

Neitsch, S. L., Arnold, J. G., Kiniry, J. R., and Williams, J. R.: Soil and Water Assessment Tool - Theoretical Documentation - Version 2005, Grassland, Soil and Water Research Laboratory, Agricultural Research Service and Blackland Research Center, Texas Agricultural Experiment Station, Temple, Texas, USA, 2005.

Ngigi, S. N., Savenije, H. H. G., Rockström, J., and Gachene, C. K.: Hydro-economic evaluation of rainwater harvesting and management technologies: Farmers' investment options and risks in semi-arid Laikipia district of Kenya, Phys. Chem. Earth, 30, 772-782, 2005.

Notarnicola, C., Angiulli, M., and Posa, F.: Soil moisture retrieval from remotely sensed data: Neural network approach versus Bayesian method, IEEE T. Geosci. Remote, 46, 547-557, 2008.

Olivera, F., Valenzuela, M., Srinivasan, R., Choi, J., Cho, H. D., Koka, S., and Agrawal, A.: ArcGIS-SWAT: A geodata model and GIS interface for SWAT, J. Am. Water Resour. As., 42, 295- 
309, 2006.

Prihar, S. S., Jalota, S. K., and Steiner, J. L.: Residue management for reducing evaporation in relation to soil type and evaporativity, Soil Use Manage., 12, 150-157, 1996.

R Development Core Team: R: A language and environment for statistical computing, http://www.R-project.org, R Foundation for Statistical Computing, Vienna, Austria, 2008.

Ramakrishnan, D., Durga Rao, K. H. V., and Tiwari, K. C.: Delineation of potential sites for water harvesting structures through remote sensing and GIS techniques: a case study of Kali watershed, Gujarat, India, Geocarto International, 23, 95-108, 2008.

Reynolds, C. A., Jackson, T. J., and Rawls, W. J.: Estimating available water content by linking the FAO soil map of the world with global soil profile database and pedo-transfer functions, Proceedings of the AGU 1999 Spring Conference, Boston, MA, USA, 31 May-4 June, 1999.

Ritchie, J. T.: Model for Predicting Evaporation from a Row Crop with Incomplete Cover, Water Resour. Res., 8, 1204-1213, 1972.

Rockström, J.: Water for food and nature in drought-prone tropics: vapour shift in rain-fed agriculture, Philos. T. R. Soc. B, 358, 1997-2009, 2003.

Rockström, J., Folke, C., Gordon, L., Hatibu, N., Jewitt, G., de Vries, F. P., Rwehumbiza, F., Sally, H., Savenije, H., and Schulze, R.: A watershed approach to upgrade rainfed agriculture in water scarce regions through Water System Innovations: an integrated research initiative on water for food and rural livelihoods in balance with ecosystem functions, Phys. Chem. Earth, 29, 1109-1118, 2004.

Rockström, J., and Barron, J.: Water productivity in rainfed systems: overview of challenges and analysis of opportunities in water scarcity prone savannahs, Irrigation Sci., 25, 299-311, 2007.

Ruget, F., Brisson, N., Delecolle, R., and Faivre, R.: Sensitivity analysis of a crop simulation model, STICS, in order to choose the main parameters to be estimated, Agronomie, 22, 133-158, 2002.

Savenije, H. H. G.: The importance of interception and why we should delete the term evapotranspiration from our vocabulary, Hydrol. Process., 18, 1507-1511, 2004.

Schulze, R. E., Schmidt, E. J., and Smithers, J. C.: Visual SCS SA. User Manual. Version 1.0. PC-based SCS design flood estimates for small catchments in southern Africa, School of Bioresources Engineering and Environmental Hydrology, University of KwaZulu-Natal, Pietermaritzburg, South Africa, 89 pp., 2004.

Schulze, R. E. (Ed.): South African Atlas of Climatology and Agrohydrology. WRC Report 1489/1/06, Water Research Commission, Pretoria, South Africa, 2007.

Schuol, J., Abbaspour, K. C., Yang, H., Srinivasan, R., and Zehnder, A. J. B.: Modeling blue and green water availability in Africa, Water Resour. Res., 44, W07406, doi:10.1029/2007WR006609, 2008.

Senay, G. B. and Verdin, J. P.: Developing index maps of waterharvest potential in Africa, Appl. Eng. Agric., 20, 789-799, 2004.
Smith, H. J.: Development of a systems model facilitating action research with resource-poor farmers for sustainable management of natural resources, Ph.D., Faculty of Biological and Agricultural Sciences, Centre for Sustainable Agriculture, University of the Free State, Bloemfontein, South Africa, 295 pp., 2006.

Spearman, C.: The proof and measurement of association between two things, Am. J. Psychol., 15, 72-101, 1904.

Statistics South Africa: Census of Agriculture Provincial Statistics 2002 - KwaZulu-Natal, Statistics South Africa, Pretoria, South Africa, 116 pp., 2006.

Taylor, V., Schulze, R. E., Jewitt, G. P. W., Pike, A., and Horan, M. J. C.: Practical issues of HELP: Examples from the Thukela Basin in South Africa, Proceedings of the AWRA/University of Dundee International Specialty Conference on Globalization and Water Management, Dundee, Scotland, 2001.

UN: World Population Prospects: The 2008 Revision, United Nations (UN) Department of Economic and Social Affairs, Population Division, New York, USA, ESA/P/WP.210, 109 pp., 2009.

Walker, S., Tsubo, M., and Hensley, M.: Quantifying risk for water harvesting under semi-arid conditions - Part II. Crop yield simulation, Agr. Water Manage., 76, 94-107, 2005.

van Griensven, A., Meixner, T., Grunwald, S., Bishop, T., Diluzio, A., and Srinivasan, R.: A global sensitivity analysis tool for the parameters of multi-variable catchment models, J. Hydrol., 324, 10-23, 2006.

Van Liew, M. W. and Garbrecht, J.: Hydrologic simulation of the Little Washita River Experimental Watershed using SWAT, J. Am. Water Resour. As., 39, 413-426, 2003.

Wang, X., He, X., Williams, J. R., Izaurralde, R. C., and Atwood, J. D.: Sensitivity and uncertainty analyses of crop yields and soil organic carbon simulated with EPIC, T. ASAE, 48, 1041-1054, 2005.

Wechsung, F., Krysanova, V., Flechsig, M., and Schaphoff, S.: May land use change reduce the water deficiency problem caused by reduced brown coal mining in the state of Brandenburg?, Landscape Urban Plan., 51, 177-189, 2000.

Woyessa, Y. E., Pretorius, E., Hensley, M., van Rensburg, L. D., and van Heerden, P. S.: Up-scaling of rain-water harvesting for crop production in the communal lands of the Modder River basin in South Africa: Comparing upstream and downstream scenarios, Water Sa, 32, 223-228, 2006.

Yang, H. and Zehnder, A.: "Virtual water": An unfolding concept in integrated water resources management, Water Resour. Res., 43, W12301, doi:10.1029/2007WR006048, 2007.

Yang, J., Reichert, P., Abbaspour, K. C., Xia, J., and Yang, H.: Comparing uncertainty analysis techniques for a SWAT application to the Chaohe Basin in China, J. Hydrol., 358, 1-23, 2008. 